\title{
Spatio-Temporal Distribution of Greenhouses and Affecting Driving Factors in Al-Batinah South, Oman, Using GIS Mapping
}

\author{
Asma M. Al-Maimani, Abdulrahim M. Al-Ismaili *, Ali K. Al-Maktoumi and Yassine Charabi \\ *Department of Soils, Water and Agricultural Engineering, Faculty of Agricultural Engineering, Sultan Qaboos University, Muscat,
} Sultanate of Oman.

Received date: 12 February 2019, Accepted date: 15 May 2019, Online date: 3 June 2019

Address for Correspondence:
Abdulrahim M. Al-Ismaili, Department of Soils, Water and Agricultural Engineering, Faculty of Agricultural Engineering, Sultan
Qaboos University, Muscat, Sultanate of Oman.
E-mail: abdrahim@ squ.edu.om; abdrahim@ @otmail.co.uk

Copyright $\odot 2019$ by authors and American-Eurasian Network for Scientific Information.

This work is the censed under the Creative Commons Attribution International License (CC BY).

http://creativecommons.org/licenses/by/4.0/

\section{(C) (i) Open Access}

\begin{abstract}
Geographic Information System (GIS) tools have been utilized in greenhouse cropping systems for detection, identifying, and mapping. This study aimed to study the spatiotemporal distribution of greenhouses (GHs) and the driving factors affecting this distribution in Al-Batinah South, Oman using GIS Mapping. First, a field survey was conducted between July and December 2017 to all farms with greenhouses (GH farms) in the study area. Second, the required digital and non-digital data were collected from different sources. Third, for 2017, the recorded geographic coordinates of GHs and GH farms were mapped, while the aerial photographs for 2008 using ArcMap 10.1 were used to study the spatial and temporal distribution of GH farms and GHs. Fourth, four main driving factors were selected: distance to various market-outlets, distance to roads, distance to coastline and effects of groundwater quality to observe their significance on the spatial distribution of GH farms in 2017 using simple regression analysis. Fifth, the most driving factors explaining the variance of $\mathrm{GH}$ farms spatial distribution in 2017 were extracted using Principle Component Analysis (PCA). The results revealed that, for 2017, the distribution of greenhouse farms varied insignificantly (p>0.05) among the six cities in Al-Batinah South, where $71 \%$ and $53 \%$ of greenhouses and greenhouse farms were concentrated only in Barka coastal city. For the period 2008-2017, the density of greenhouse farms and greenhouses were shifting towards the inland cities such as Nakhal, Al-Rustaq, and Awabi. Within the same period, there was an average reduction of several greenhouses and greenhouse farms by 16.2 and 2.2, respectively. The total land area occupied by greenhouses shrank by an average of $0.56 \mathrm{ha} /$ year in the same period. Results displayed that only one of the four main driving factors had a statistically significant influence $(p<0.05)$ on the spatial distribution of greenhouse farms in 2017 , which was the distance to roads. The most affecting driving factors on this distribution was the distance to local markets and the distance to Al-Mawaleh Central market by accounting for $\mathbf{4 4 . 2 \%}$ and $23.8 \%$ of the total variance, respectively. In conclusion, Over the period 2008-2017, there was an overall reduction in the average number of GH farms and GHs due to land use changes, high construction costs (capital cost), high production costs, fuel cost, pests and diseases, water scarcity (in some places), competition due to foreign produce and from high tech domestic, low subsidy by Ministry of Agricult ure and Fisheries and/or price fluctuations of fresh produce. The influence of distance to the highway and distance to the nearest paved roads were found significant driving factors $(p<0.05)$. Based on PCA analysis, distance to local markets, and distance to Al-Mawaleh Central market were the two driving factors describing the total variance of GH farms spatial distribution. It is recommended, for future expansion of greenhouse farms, to consider inland areas with low groundwater salinity and to consider other driving factors such as soil parameters and distance to urban settlements for their potential significance on the spatial distribution of GHs and GH farms. This study will help decision-makers in future development and planning of GH agribusiness.
\end{abstract}

KEYWORDS

Greenhouses, distribution, temporal, driving factors, GIS, Oman. 
Asma M. Al-Maimani et al., 2019. Spatio-Temporal Distribution of Greenhouses and Affecting Driving Factors in Al-Batinah South, Oman, Using GIS Mapping / American-Eurasian Journal of Sustainable Agriculture. 13(2): 13-33. DOI: 10.22587/aejsa.2019.13.2.2

\section{INTRODUCTION}

In Oman, most the agricultural lands are concentrated in a narrow strip of Al-Batinah coastal plain [1, 2] which accounts for 50 to $65 \%$ of the total agricultural production [3]. This area has exhibited a dynamic agricultural development in recent years [3]. However, this area is also the highest area in terms of freshwater consumption because agriculture is the largest water consumer, with almost $78 \%$ of the total water consumption globally [4]. Groundwater is the main source of irrigation in the agricultural sector in Oman [5]. High temperatures and water scarcity are the two major threats to open-field cultivation in Oman [6]. Controlled Environment Agriculture (CEA) is an applicable option for sustainable crop production to overcome the adverse climatic conditions [7] by providing relatively cool atmosphere especially in an arid and hot area like the Arabian peninsula and consuming less irrigation water [5]. CEA is a term that covers a variety of agricultural systems including shade-houses, screen houses, greenhouses and aquaponics.

In Oman, the Ministry of Agriculture and Fisheries (MAF) started to adopt this technology by the end of the 1980s. The most important reasons that the government introduced this technology among the farmers were to increase land and water use efficiencies. It was reported that the land and water use efficiencies from greenhouse cultivation increased by 12 and 2 folds, respectively, compared to open field cultivation. The number of CEA systems escalated from 781 in 2001 to 5563 in 2015 [8]. Also, by the end of 2013, the total area under CEA expanded to 237.6 ha [9]. GHs represent $92 \%$ of total CEA systems in Oman, while the remaining $8 \%$ includes shade houses [8].

Globally, the use of greenhouses (GHs) in food production has increased owing to their high productivity and economic benefits [10]. The land area occupied by plastic GHs exceeded 500,000 ha; where south-east of Asia have the most significant concentrations followed by the Mediterranean basin [11].

Rapid expansion and shifting of CEA systems from one location to another should be planned and mapped for the development and management of natural resources. Many researchers have reported that Geographic Information System (GIS) is an effective technique which was used to build a Database Management System (DBMS) for protected cultivation [12]. For CEA in Oman, Deadman, Al-Sadi, Al-Wardi, Al-Kiyumi, Deadman and Al Said [13] studied the distribution of GHs and the spatio-temporal dynamics of land use changes affected by external pressures in northern Oman. Integration of Remote Sensing (RS) and GIS techniques are very beneficial and widely utilized in mapping and managing natural resources and building environmental models [14]. In CEA, satellite imageries and GIS tools were used for generating DBMS [15] and detecting plasticcovered CEA units [16]. In many parts of the world, GIS and RS are effectively utilized to provide updated information about GHs. However, there is a lack of information in the utilization of aerial photographs and satellite imagery integrated with GIS technique to identify and map GHs or to study the spatio-temporal distribution of GHs and the driving factors affecting this distribution in Oman.

This study aimed to investigate the spatio-temporal distribution of GHs and the driving factors affecting this distribution in Al-Batinah South, Oman using GIS Mapping. The specific objectives were 1) to illustrate the spatial distribution of GHs in Al-Batinah South in 2017, using ArcMap 10.1 and the temporal distribution in two years; 2008 and 2017, 2) to study the influence of four main driving factors: nearness to various market-outlets (local markets and central market), nearness to roads (highway and nearest paved road), effect of groundwater quality and distance to coastline, and 3) to analyse the significance of each driving factor on the spatial distribution of GH farms in the study area in 2017 using simple regression analysis. This paper will also examine the most driving factors explaining the variance of GH farms spatial distribution in 2017 using Principle Component Analysis (PCA).

\section{MATERIALS AND METHODS}

Study area

Al-Batinah South governorate was selected as the study area because it has the highest number of GHs among other governorates in Oman [17]. It is located in the northern part of Oman on the Sea of Oman (Fig.1) at latitudes: $23^{\circ} 42^{\prime} 28^{\prime \prime}$ to $23^{\circ} 32^{\prime} 55^{\prime \prime} \mathrm{N}$ and longitudes: $57^{\circ} 19^{\prime} 49^{\prime \prime}$ to $58^{\circ} 03^{\prime} 28^{\prime \prime}$ E. The selected study area comprises six cities: Al-Rustaq, Awabi, Nakhal, Wadi Al-Maawil, Barka and Al-Musannah. These cities are characterized by a very hot, humid summer and a warm, low-humidity winter, where the annual average air temperature is $28.5^{\circ} \mathrm{C}$ in the coastal area and $17.8^{\circ} \mathrm{C}$ in the mountains. Al-Batinah region is a low-lying alluvial plain that produces about $65 \%$ of the agricultural production in the country [3]. Thus, this governorate is critically essential to the agriculture economy of Oman. In Oman, farmers mainly grow cucumber in greenhouses $(90 \%)$, followed by tomatoes $(5-9 \%)$ [8].

Data collection and analyses

The study approach was divided into 5 parts, as shown in Fig. 2. A field survey through a single visit to all farms with GHs (GH farms) in Al-Batinah South was conducted between July and December 2017. During these visits, the geographic coordinates of greenhouses and farm gates were recorded using GPS devices, and 
Asma M. Al-Maimani et al., 2019. Spatio-Temporal Distribution of Greenhouses and Affecting Driving Factors in Al-Batinah South, Oman, Using GIS Mapping / American-Eurasian Journal of Sustainable Agriculture. 13(2): 13-33. DOI: 10.22587/aejsa.2019.13.2.2

the measurements of length and width of each GH were taken. The collection of digital and non-digital data from different sources was done, as shown in Table 1.

For the spatial distribution of GHs and GH farms in 2017, the recorded geographic coordinates were converted to a layer in ArcMap 10.1. For 2008, aerial photographs were used to identify the spatial locations of farm gates and GHs. Each image covers an area of $4 \mathrm{~km} \times 2 \mathrm{~km}$, with a total of 735 images processed into a mosaic in ArcMap 10.1. Images were already georeferenced to the coordinate system of UTM (Universal Transverse Mercator), with Datum of WGS 84 (World Geodetic System 1984) for Zone 40 where Oman is located. The farm gates and GHs with existing structures were digitized in ArcMap 10.1. Also, each GH type (single-, double- or multi-span) was inserted in an attribute table.

Moreover, the pattern of GHs distribution was observed through the Average Nearest Neighbour tool in ArcMap 10.1 for 2008 and 2017. The stated null hypothesis was that "the distribution of GHs is dispersed in the study area at a significant level of 0.05 for both years". The changes in the land area occupied by GHs were also studied. In 2017, The field measurements for each GH were used to calculate the total land areas covered by GHs, while for 2008, a GH from each type (single, double and multi-span GHs) with standard size [18] was digitized (polygon) in ArcMap 10.1 to estimate the total land area of GHs.

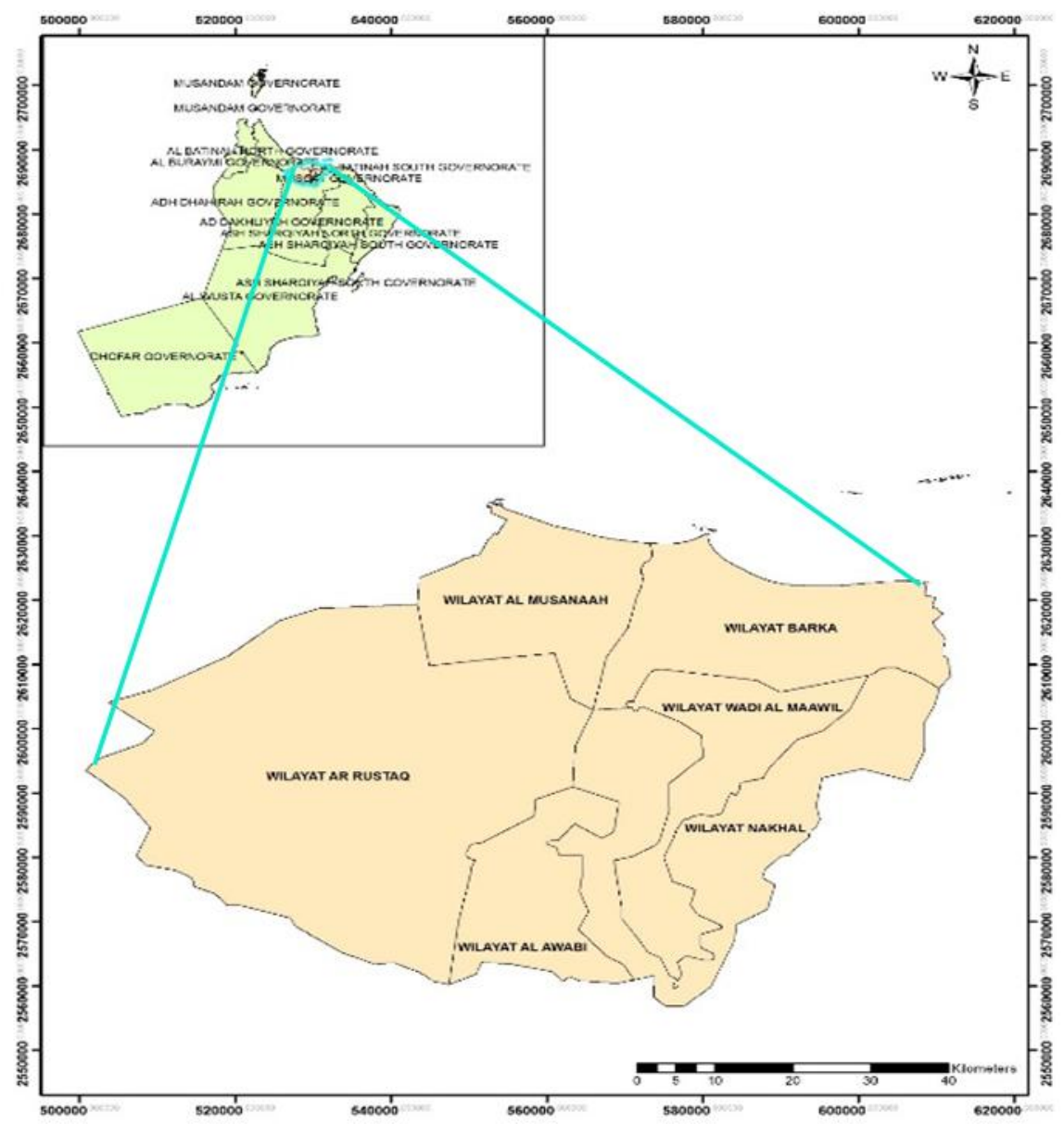

Figure 1: Al-Batinah South Governorate concerning the map of Oman (top left) 
Asma M. Al-Maimani et al., 2019. Spatio-Temporal Distribution of Greenhouses and Affecting Driving Factors in Al-Batinah South, Oman, Using GIS Mapping / American-Eurasian Journal of Sustainable Agriculture. 13(2): 13-33. DOI: 10.22587/aejsa.2019.13.2.2

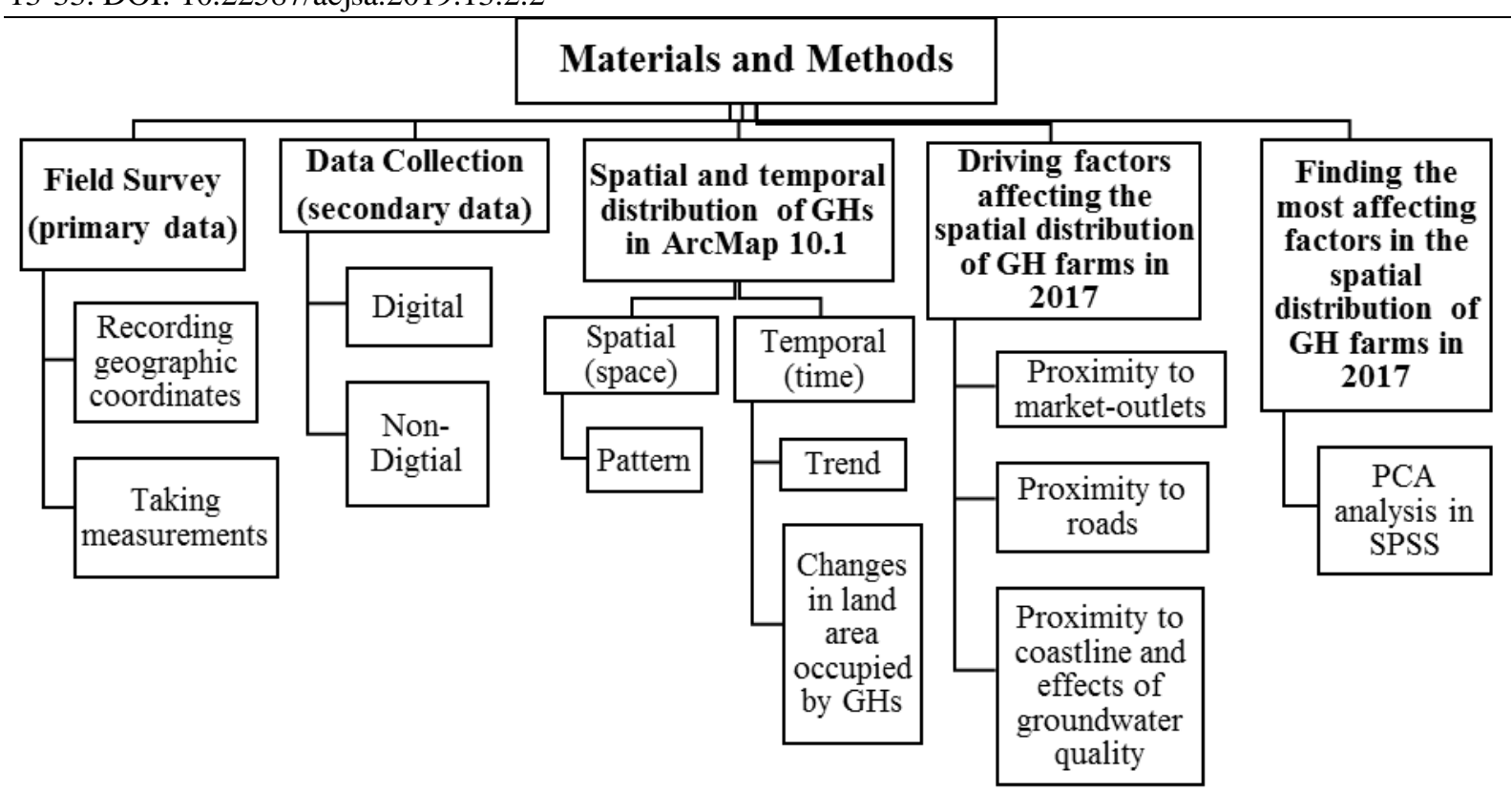

Figure 2: Diagram of data collection and analyses

Table 1: Data and the sources used in this study

\begin{tabular}{|c|c|c|c|}
\hline Year & Data & Description & Source of data \\
\hline 2008 & $\begin{array}{l}\text { Geographic coordinates of farms } \\
\text { and GHs }\end{array}$ & $\begin{array}{c}\text { Aerial photographs } \\
\text { (mosaic), Resolution: } \\
0.5 \mathrm{~m}\end{array}$ & National Survey Authority (NSA) \\
\hline 2017 & $\begin{array}{l}\text { Geographic coordinates of farms } \\
\text { and GHs }\end{array}$ & & Field measurements \\
\hline 2017 & Attribute data of farms and GHs & & Field measurements \\
\hline 2017 & Map of Al-Batinah South & Digital format (.shp) & NSA \\
\hline 2017 & $\begin{array}{l}\text { Geographic coordinates of Local } \\
\text { markets }\end{array}$ & $\begin{array}{l}\text { As guided by local } \\
\text { people in each city }\end{array}$ & Google Earth Pro \\
\hline \multirow[t]{2}{*}{2017} & $\begin{array}{l}\text { Geographic coordinates of Al- } \\
\text { Mawaleh central market for fruits } \\
\text { and vegetables }\end{array}$ & Landsat image (2017) & Google Earth Pro \\
\hline & Road network & Digital format (.shp) & NSA \\
\hline \multirow[t]{2}{*}{$\begin{array}{c}2005 \& \\
2016\end{array}$} & $\begin{array}{l}\text { Geographic coordinates of wells } \\
\text { and their EC data }\end{array}$ & & $\begin{array}{l}\text { Ministry of Regional } \\
\text { Municipalities and Water } \\
\text { Resources (MRMWR) }\end{array}$ \\
\hline & $\begin{array}{c}\text { Map of Al-Batinah South } \\
\text { catchments }\end{array}$ & & MRMWR \\
\hline
\end{tabular}

Analysis of driving factors affecting the spatial distribution of GH farms in 2017

Proximity to market-outlets: It is important to build GH farms near the market outlets because of the high value of GH products and their perishable nature [19]. To study this factor, for 2017, farm gates of GH farms were linked to local markets at each city and Al-Mawaleh central market for fruits and vegetables in Muscat which is the biggest outlet of products in Oman. In ArcMap 10.1, buffer tool was applied to create zones at $2 \mathrm{~km}$ intervals around each local market in 6 different layers. After that, the clip tool was applied to extract the number of GH farms at each interval in 6 cities. Similarly, the buffer tool was used to create zones around the central market layer at $5 \mathrm{~km}$ intervals starting from Al-Batinah South border at $18 \mathrm{~km}$. After that, the clip tool was applied to extract the number of GH farms at each interval. Finally, simple regression test was applied in SPSS software (version 20, IBM, USA) to study the effect of proximity to the local markets and central market outlets as driving factors on the spatial distribution of GH farms (\%) in 2017.

Proximity to roads: Road network is an essential factor in enhancing the suitability of a region for horticulture, commercial, and other activities. The fresh agricultural produce is highly perishable and requiring appropriate transportation ways to markets. Thus, building GHs in remote areas will increase the postharvest 
Asma M. Al-Maimani et al., 2019. Spatio-Temporal Distribution of Greenhouses and Affecting Driving Factors in Al-Batinah South, Oman, Using GIS Mapping / American-Eurasian Journal of Sustainable Agriculture. 13(2): 13-33. DOI: 10.22587/aejsa.2019.13.2.2

losses and may constrain investors or farmers to recover the investment costs. Justus and $\mathrm{Yu}$ [20] mentioned that transport costs have a significant effect on the total cost of marketing. Thus, the proximity of farms to paved roads could offer faster access to the main highways and therefore to market outlets. To study this factor, each farm gate was linked with a road network to analyze the influence of roads (highway road and nearest paved road) on the spatial distribution of GH farms in 2017. In ArcMap 10.1, buffer zones within $5 \mathrm{~km}$ and $1 \mathrm{~km}$ were created around Al-Batinah highway and all paved roads layers using buffer tool. After that, the number of GH farms was extracted from both layers using the clip tool. Finally, to study the effect of proximity to roads as driving factor on the spatial distribution of GH farms (\%) in 2017, a simple regression test was done in SPSS software.

Proximity to coastline and effects of groundwater quality: Groundwater is the main source of irrigation in the agricultural sector in Oman [5]. Thus mapping would be beneficial to provide an assessment of groundwater quality in the study area. Salinity data for the observation wells within different catchments monitored by the Ministry of Regional Municipalities and Water Resources were available for 2005 and 2016 years [21]. These data were used to map and analyze the spatial variations of groundwater salinity within the study area via an interpolation approach of the geostatistical analyst tool in ArcMap 10.1. This could provide more insights about the possible impact of groundwater salinity on redistribution of GH farms. In SPSS, simple regression test was applied to study the effect of interpolated groundwater salinity (EC) in 2016 as a driving factor on the spatial distribution of GH farms (\%) in 2017. In ArcMap 10.1, buffer zones within $5 \mathrm{~km}$ intervals were created around the coastline layer towards inland using buffer tool. Moreover, the number of GH farms was extracted from each interval for the years 2008 and 2017 using the clip tool. Simple regression test in SPSS was applied to study the influence of proximity to the coastline on the spatial distribution of GH farms (\%) in 2017.

Most affecting driving factor/s on the spatial distribution of GH farms in 2017

Assuming all of the driving above factors have a significant effect on the spatial distribution of GH farms, the factorial analysis was applied to investigate the most contributing driving factors in the spatial distribution of GH farms for 2017. Principle Component Analysis (PCA) is a statistical tool used for identifying the essential input variables that are explaining a specific issue [22]. Therefore, PCA was utilized to find the most driving factor/s affecting the spatial distribution of GH farms in 2017.

\section{Spatial distribution of GHs in 2017}

\section{RESULTS AND DISCUSSION}

The results of the field survey analysis revealed that the total number of GH farms visited in the study area was 98 farms, Table 2. The distribution of GH farms varied insignificantly ( $p>0.05)$ between cities. Among the six cities in Al-Batinah South, Barka had the highest density of GH farms (53\%), followed by Al-Musannah $(23 \%)$ and the least number was in other cities (24\%). Similarly, $71 \%$ of the GHs were concentrated in Barka and only $29 \%$ of GHs were located in Al-Musannah, Nakhal, Wadi Al-Maawil, Al-Rustaq, and Awabi. The number of GHs in all farms was ranging between 1 and 29 , and only one farm had 79 GHs. The spatial distribution of GHs according to their number in each farm is illustrated in Fig. 3. From Fig. 4, it can be noticed that most GH farms had less than 5 GHs (55\%) with a mean number of GHs per farm of 6.7 (Stdev=9.7 GH). This indicates that most GH farms in the surveyed area were considered "small scale," according to MAF and ICARDA [5]. A less density of GHs was noticed in the interior part of Al-Batinah South. This could be attributed to the variation in soil type where typic Gypsiorthids gravelly loam (upstream at the foothills) is present in inland areas and typic Salorthids (downstream at the coastline) in coastline [23].

Using the Definition Query in ArcMap 10.1, 6 clusters of GHs (a group of GHs >20 per farm) in the study area were identified. Five of these clusters were located in Barka; 2 in the eastern part of Barka and 3 in the western part, while the last cluster was in Nakhal. From the Average Nearest neighbor tool in ArcMap 10.1, it was found that the overall pattern of GHs distribution within the study area was a "clustered" pattern $(p<0.05)$.

\section{Temporal distribution of GHs in 2008 and 2017}

For the whole period 2008-2017, it was observed that the average number of GH farms and the number of GHs in Al-Batinah South declined by 2.2 farm/year and $16.2 \mathrm{GH} /$ year, respectively, Fig. 5. The mean number of GHs per farm was 6.8 in 2008, then decreased slightly to 6.7 in 2017. The reduction in GH farms and GHs in the period 2008-2017 could be attributed to land use changes, high construction costs (capital cost), high production costs (e.g. seed, fertilizers and pests), fuel cost, pests and diseases, water scarcity (in some places), competition due to foreign produce, high-tech domestic and international GH competitors, low subsidy by MAF and price fluctuations of fresh produce. Barka had the highest number of GH farms $(>50 \%)$ with the highest number of GHs (>65\%) among all cities in Al-Batinah South for the study period 2008-2017, Figs. 6 and 7, respectively. During the same period 2008-2017, an overall increase in GH farms took place in Nakhal, AlRustaq and Awabi, a reduction was observed in Barka and Al-Musannah, and no change was noticed in Wadi Al-Maawil, Fig 8. A similar trend was observed with the number of GHs except for Wadi Al-Maawil, where the 
Asma M. Al-Maimani et al., 2019. Spatio-Temporal Distribution of Greenhouses and Affecting Driving Factors in Al-Batinah South, Oman, Using GIS Mapping / American-Eurasian Journal of Sustainable Agriculture. 13(2): 13-33. DOI: 10.22587/aejsa.2019.13.2.2

number of GHs dropped down, Fig 9. This means that the density of GH farms and GHs were shifting towards inland cities. The increase in GH farms and GHs in Nakhal, Al-Rustaq and Awabi could be attributed to the good groundwater quality, the increased farmers' interest in GH technology and realization of its successfulness and profitability.

Table 2: Total number of surveyed GH farms by cities

\begin{tabular}{|c|c|c|}
\hline Cities & No. of farms & No. of GHs \\
\hline Barka & 52 & 467 \\
\hline Al-Musannah & 23 & 90 \\
\hline Nakhal & 8 & 57 \\
\hline Wadi Al-Maawil & 4 & 12 \\
\hline Al-Rustaq & 5 & 10 \\
\hline Awabi & 6 & 24 \\
\hline Total & $\mathbf{9 8}$ & $\mathbf{6 6 0}$ \\
\hline
\end{tabular}

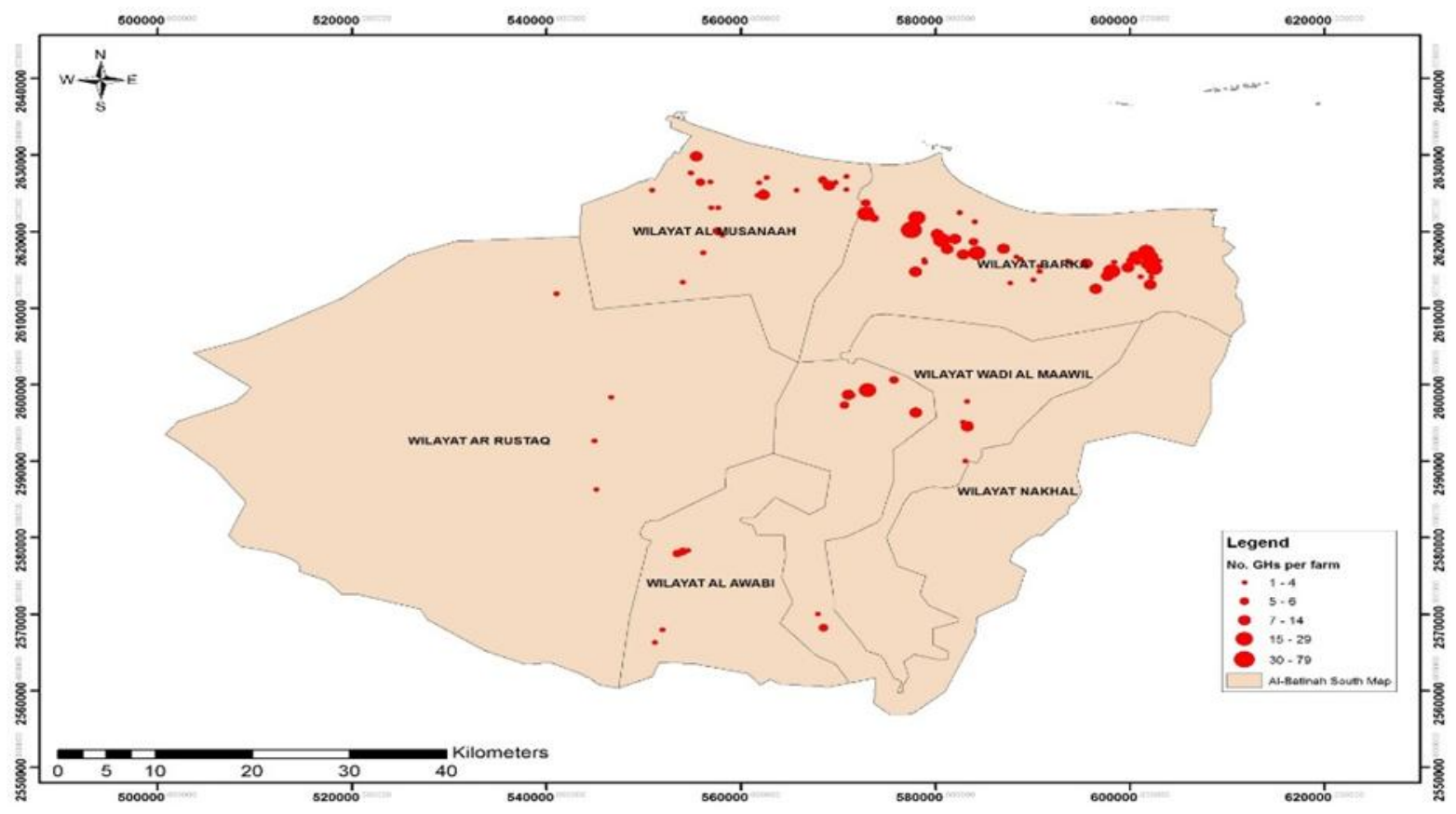

Figure 3: GHs spatial distribution according to the number of GHs in each farm for Al-Batinah South in 2017 
Asma M. Al-Maimani et al., 2019. Spatio-Temporal Distribution of Greenhouses and Affecting Driving Factors in Al-Batinah South, Oman, Using GIS Mapping / American-Eurasian Journal of Sustainable Agriculture. 13(2): 13-33. DOI: $10.22587 /$ aejsa.2019.13.2.2

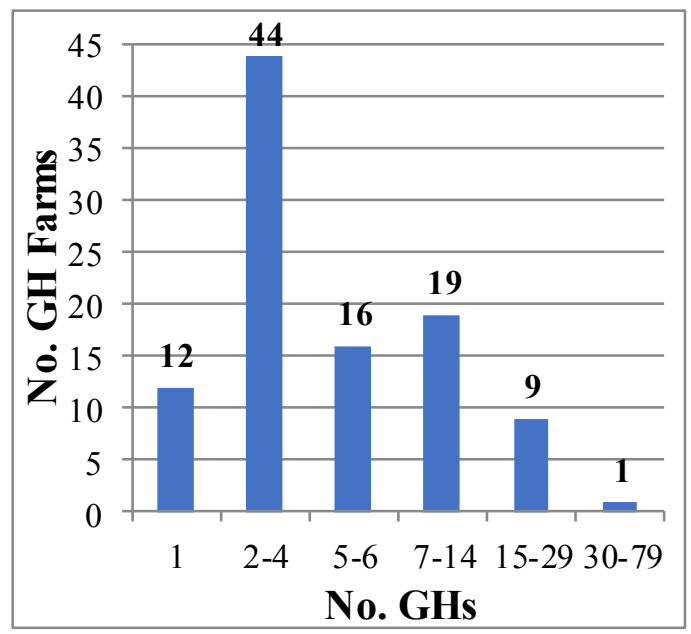

Figure 4: Range of GHs in farms

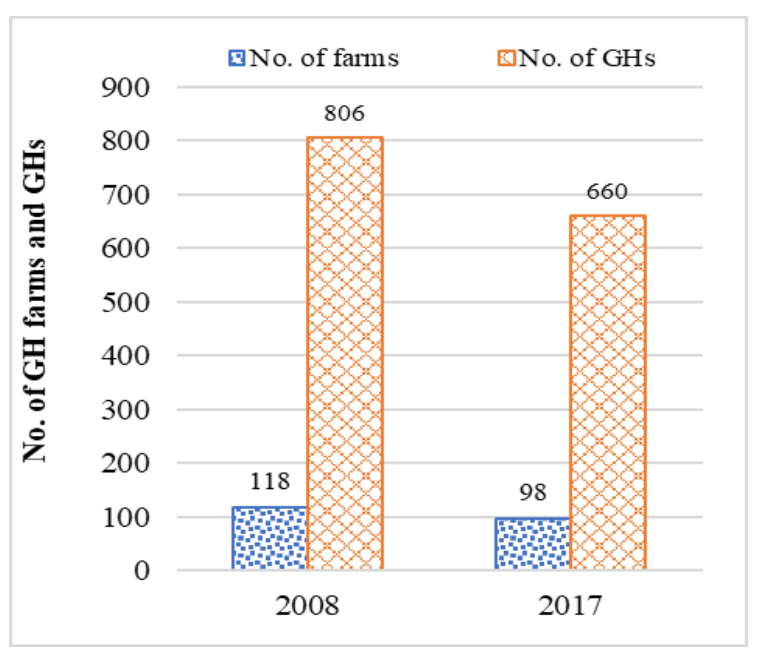

Figure 5: Number of GH farms and GHs in 2008 and 2017

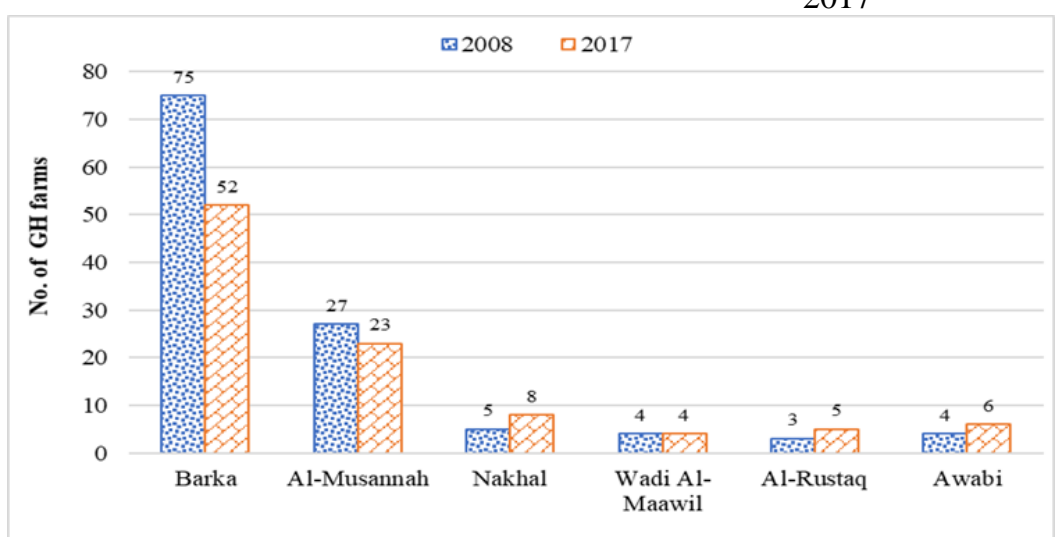

Figure 6: Number of GH farms among cities in 2008 and 2017

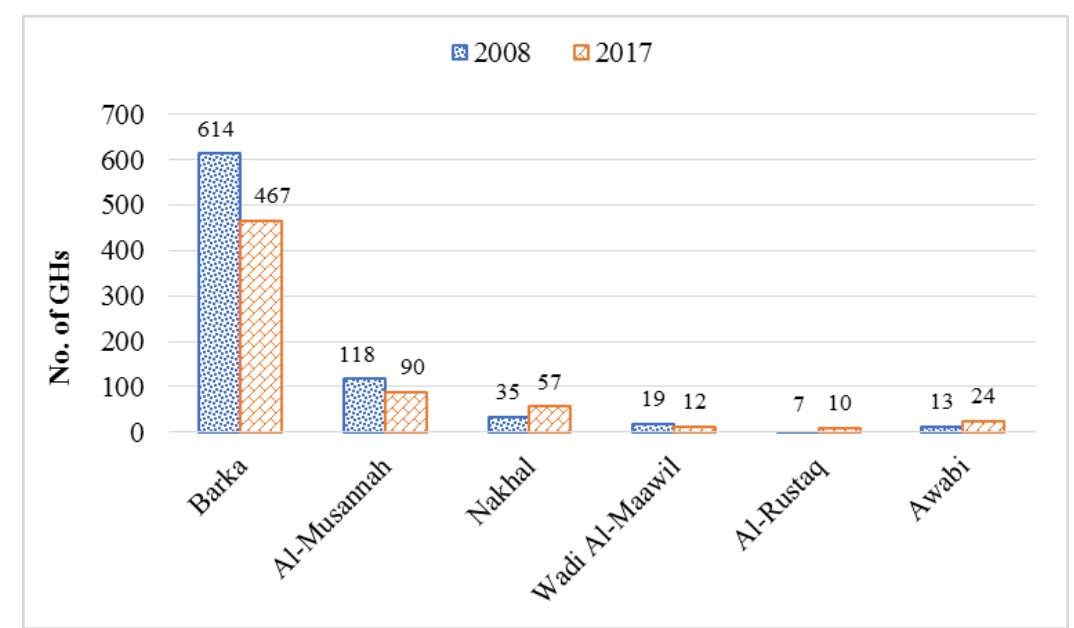

Figure 7: Number of GHs among cities in 2008 and 2017 
Asma M. Al-Maimani et al., 2019. Spatio-Temporal Distribution of Greenhouses and Affecting Driving Factors in Al-Batinah South, Oman, Using GIS Mapping / American-Eurasian Journal of Sustainable Agriculture. 13(2): 13-33. DOI: 10.22587/aejsa.2019.13.2.2

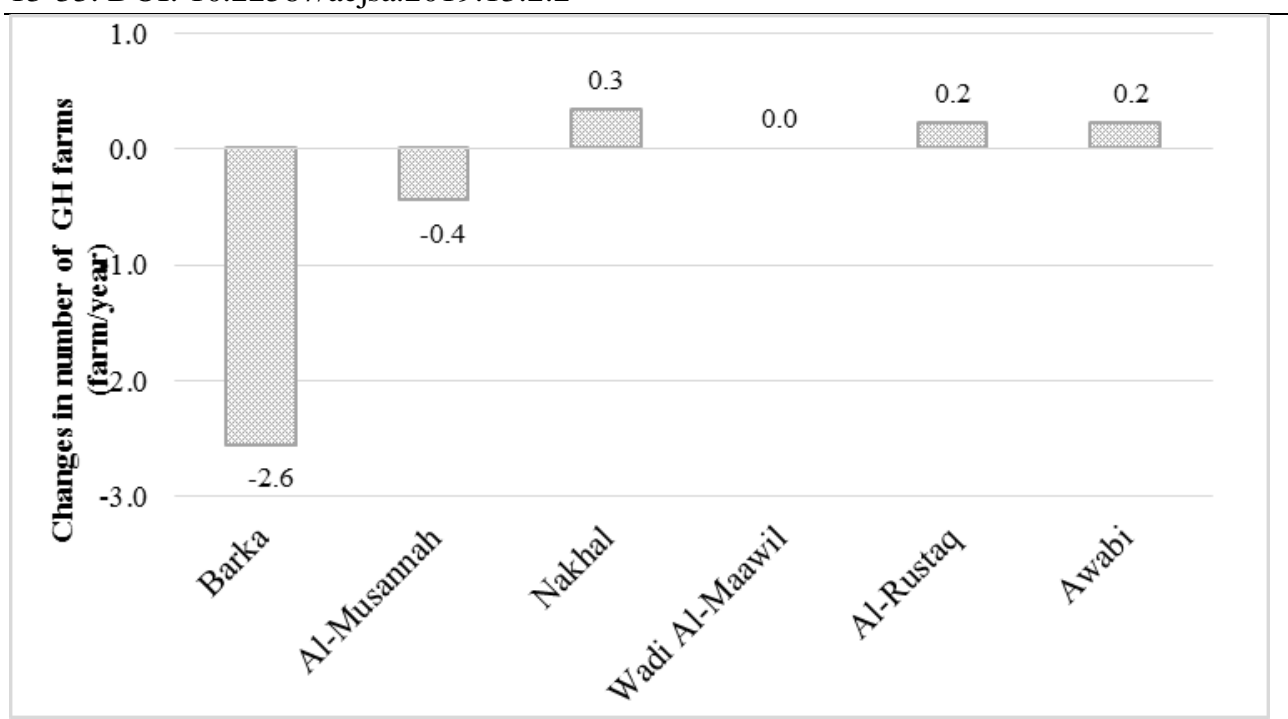

Figure 8: Average changes in number of GH farms among cities during the study period 2008-2017

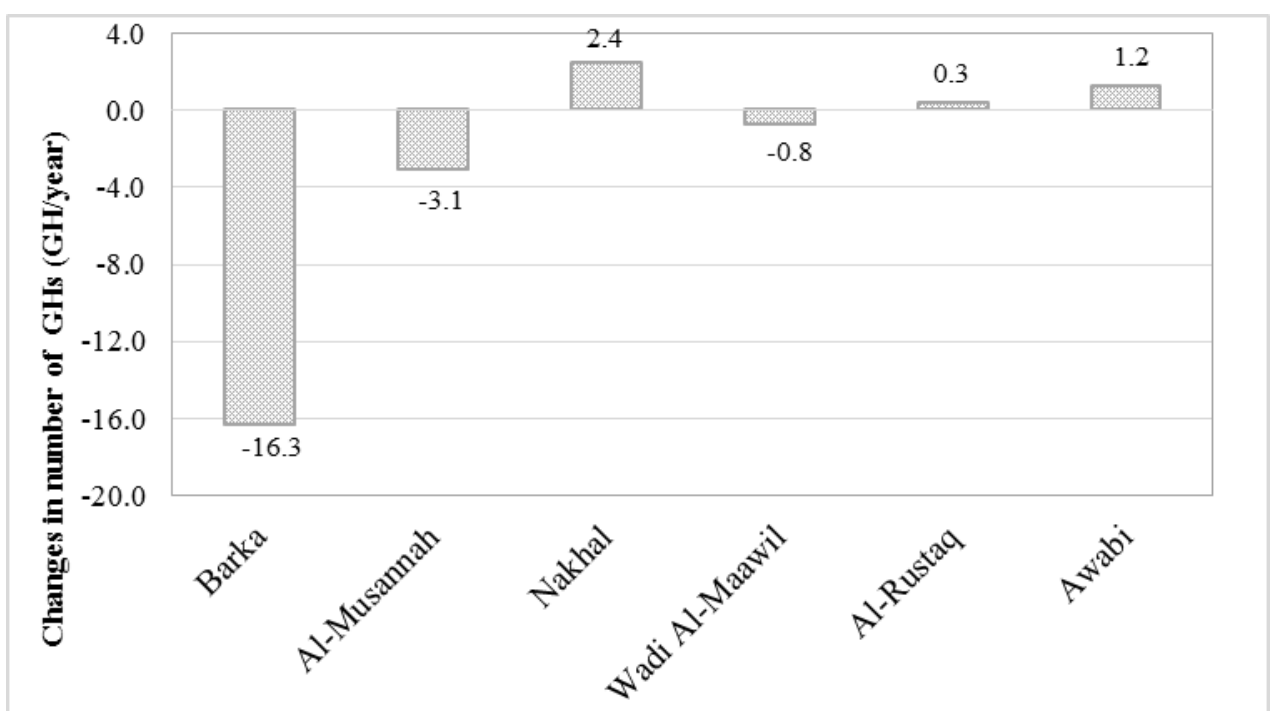

Figure 9: Average changes in the number of GHs among cities during the study period 2008-2017

On the other hand, the reduction noticed in Barka and Al-Musannah might be due to the increasing groundwater salinity, land use changes into residential or industrial and shifting from GHs to shade-houses especially in AlMusannah (noticed during the field survey in 2017). Figure 10 depicts the distribution of GHs according to the number of GHs in each farm for 2008 using ArcMap 10.1. In 2008, 54.2\% of farms had less than 5 GHs, and most of GHs were concentrated on the coastline, which is similar to the distribution in 2017 (Fig. 3). A total of 5 clusters (a group of GHs > 20 per farm) were found in Al-Batinah South in 2018; 4 clusters in Barka and 1 in AlMusannah. Based on the average nearest neighbor tool in ArcMap 10.1, the pattern of GHs distribution in 2008 was classified as clustered $(\mathrm{p}<0.05)$. This pattern could be attributed to the quality of soil and groundwater, which is better in some areas than others and to the presence of a good road network.

\section{Changes in the land area occupied by GHs}

The calculated land area occupied by GHs using the digitizing approach in ArcMap 10.1 for 2008 and from the field measurements for 2017 showed that the GH land area decreased from 30.9 ha in 2008 to 25.8 in 2017 , indicating that GH land area was shrinking at a rate of $0.56 \mathrm{ha} /$ year. This could be attributed to the expansion of urbanized lands (shifting to residential or industrial), increased soil and water problems, less subsidy by MAF, high production cost and low sale prices of products. Thus, it was essential to analyze the main factors that were driving the spatial distribution of GH farms in Al-Batinah South, as discussed below. 
Asma M. Al-Maimani et al., 2019. Spatio-Temporal Distribution of Greenhouses and Affecting Driving Factors in Al-Batinah South, Oman, Using GIS Mapping / American-Eurasian Journal of Sustainable Agriculture. 13(2): 13-33. DOI: 10.22587/aejsa.2019.13.2.2

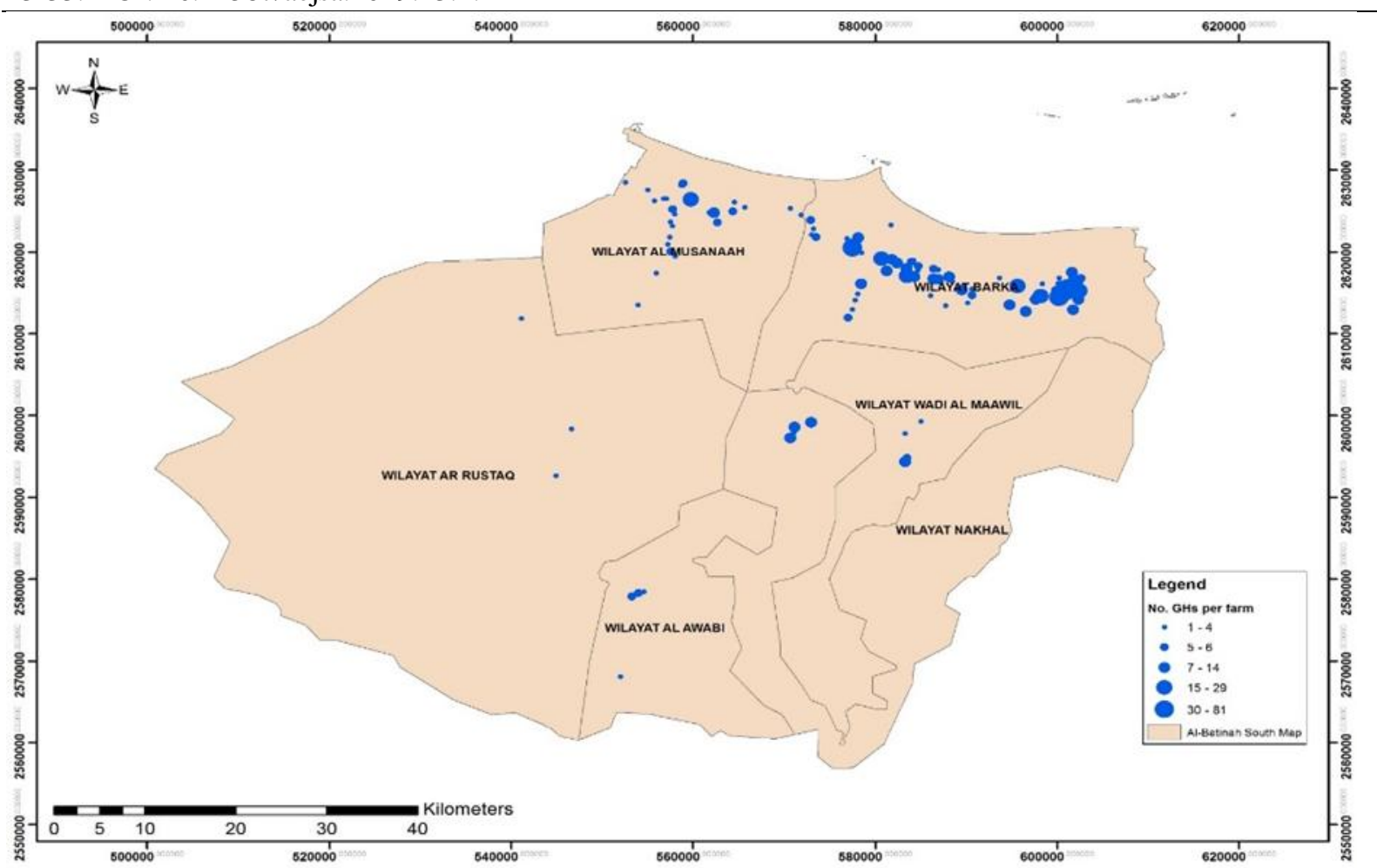

Figure 10: GHs spatial distribution according to the number of GHs in each farm in Al-Batinah South in 2008

\section{Driving Factors Affecting GH farms Distribution}

The effect of nearness to various market-outlets

Figure 11 displays the distribution of GH farms and local markets in different cities in Al-Batinah South during 2017. The results showed statistically insignificant $\left(\mathrm{p}>0.05, \mathrm{R}^{2}=0.126\right)$ influence of $\mathrm{GH}$ farms distribution concerning the distance from local markets, Fig. 12. However, there was an overall decreasing trend of GH farms (\%) with distance from local markets. Farmers did not consider this factor when they were choosing or buying farms for constructing GHs. Other factors could have contributed more significantly to the distribution of GH farms than this factor. The delivery of GH farms in the study area concerning Al-Mawaleh central Market in Muscat Governorate was statistically insignificant with the distance from Al-Mawaleh central Market ( $p>0.05$ ). The overall trend showed a decreasing percentage of GH farms with increasing distance from Al-Mawaleh central market. The correlation between the distribution and the distance from Al-Mawaleh central market was a negative and weak correlation as indicated by the $\mathrm{R}^{2}$ value of 0.215 , Fig. 13. Although the proximity to local markets and Al-Mawaleh central market was not a significant driving factor affecting the distribution of GH farms in this study, the fitted models for cumulative number of GH farms was reported to be statistically significant with distances from the local markets and Al-Mawaleh Central Market in Al-Batinah governorate for the period 2001- 2004 in another study [24]. Similarly, Maeda, Clark, Pellikka, and Siljander [25] revealed that proximity to village markets was one of the main factors driving the spatial distribution of lands brought into agriculture in the Eastern Arc Mountains in Kenya. This could indicate that farmers before 2004 were taking into consideration the nearness to market outlets as a criterion before constructing GHs, which was not the case after 2008. Dong, Xu and Zhang [26] investigated the variations in the combinations and relative importance of drivers with counties and periods. For example, the relative importance of distance to the lake in Kunshan and Changshu cities was increased compared to Changshu during 1990-2010.

\section{The effect of groundwater quality}

Figure 14 shows the groundwater catchments in the study area [21]. Between 2005-2010, the highest average inland creeping of seawater intrusion interface was found to be $357 \mathrm{~m} /$ year in Wadi Taww catchment compared to other catchments [21]. This result was based on the maximum distance of the salinity interface line of $10 \mathrm{dS} / \mathrm{m}$ which represents the severe degree of restriction on use of irrigation water based on FAO guidelines [27]. Because this average change in seawater intrusion interface was still not large, thus examining the effect of EC in 2005 with the spatial distribution of GH farms in 2008 will not be erroneous. 
Asma M. Al-Maimani et al., 2019. Spatio-Temporal Distribution of Greenhouses and Affecting Driving Factors in Al-Batinah South, Oman, Using GIS Mapping / American-Eurasian Journal of Sustainable Agriculture. 13(2): 13-33. DOI: 10.22587/aejsa.2019.13.2.2

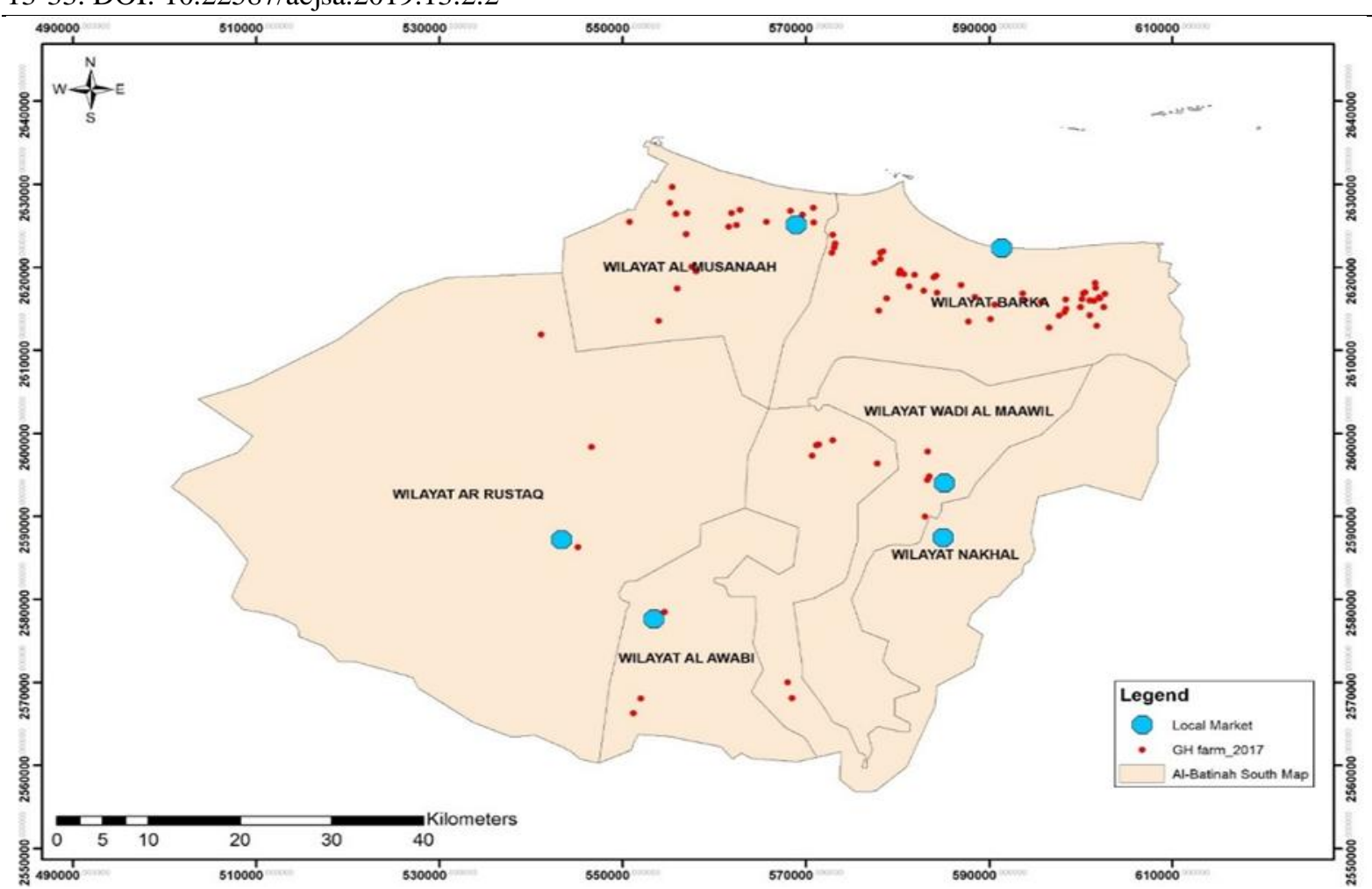

Figure 11: Distribution of GH farms in relation to local markets in Al-Batinah South cities

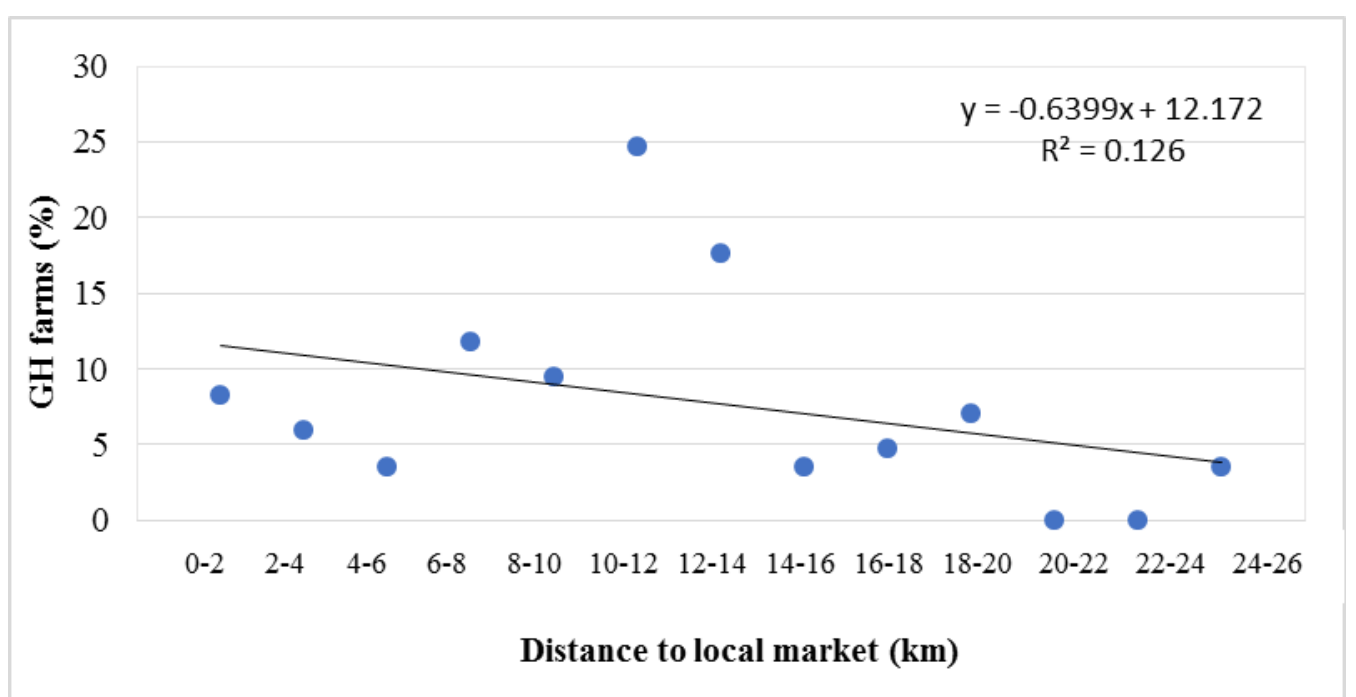

Figure 12: The percentage of GH farms within $2 \mathrm{~km}$ intervals from local markets in Al-Batinah South 
Asma M. Al-Maimani et al., 2019. Spatio-Temporal Distribution of Greenhouses and Affecting Driving Factors in Al-Batinah South, Oman, Using GIS Mapping / American-Eurasian Journal of Sustainable Agriculture. 13(2): 13-33. DOI: 10.22587/aejsa.2019.13.2.2

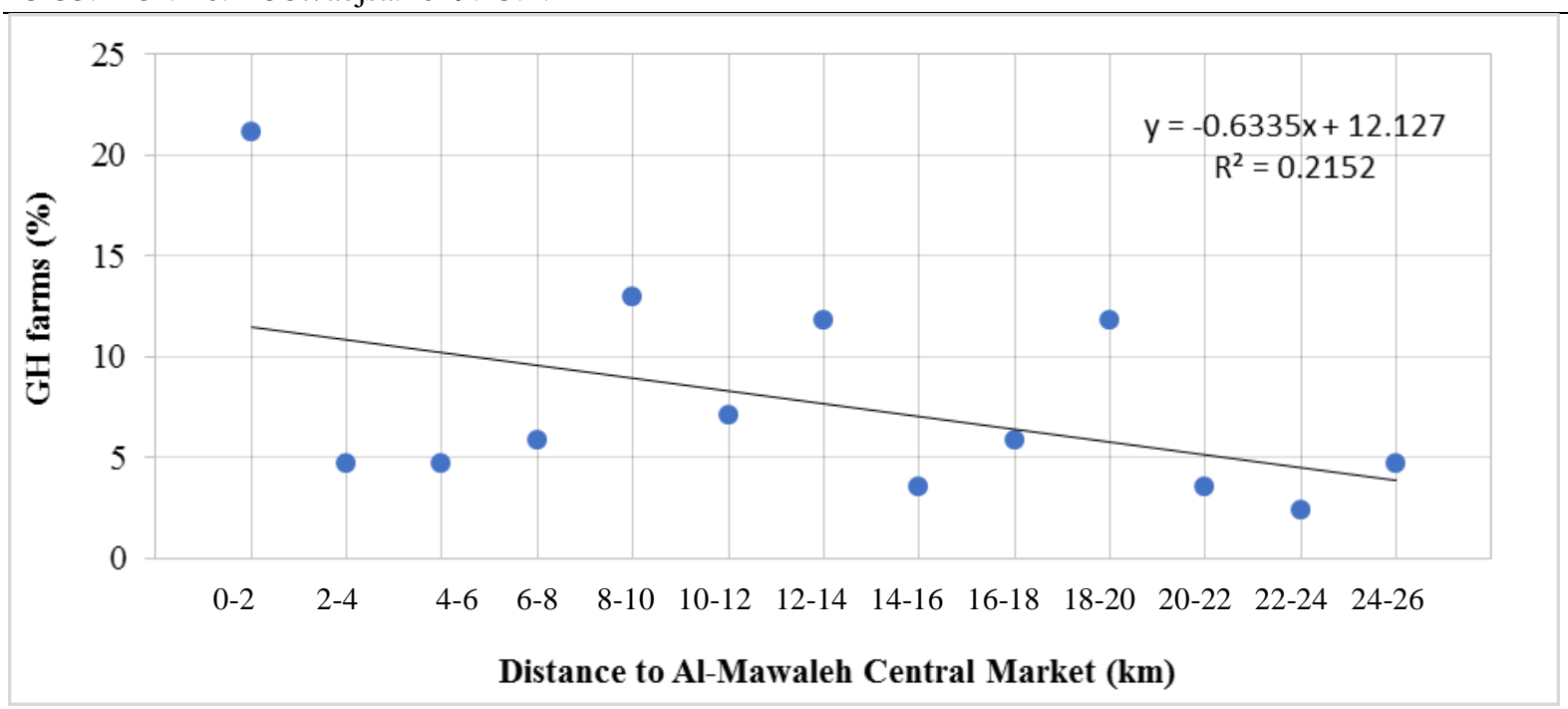

Figure 13: The percentage of $\mathrm{GH}$ farms at $5 \mathrm{~km}$ intervals from Al-Mawaleh central market starting from AlBatinah South boarder ( $\geq 23 \mathrm{~km})$

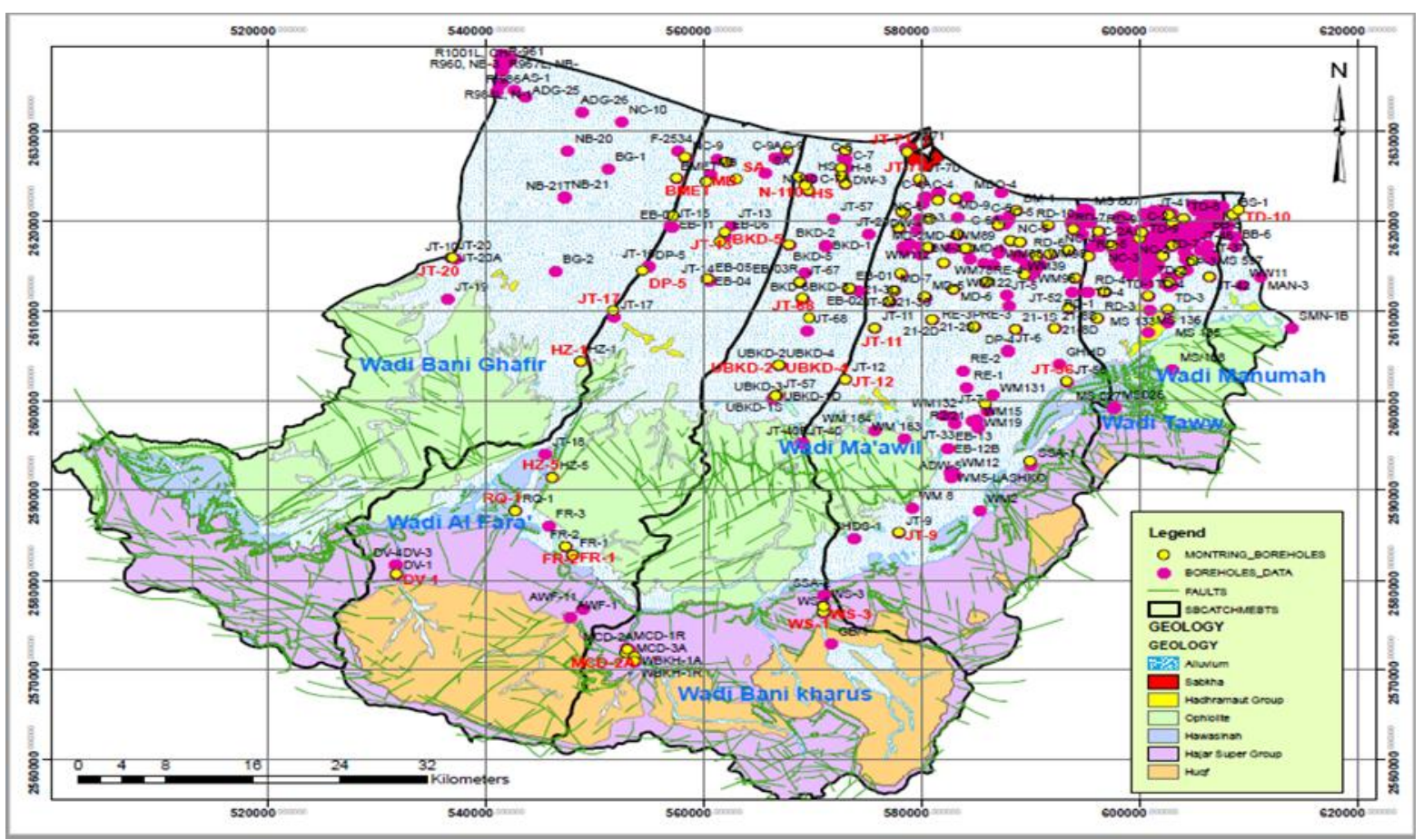

Figure 14: The catchments within Al-Batinah South [21]

Geostatistical analyses were applied to build a continuous surface for a specific feature where the interpolated feature should be normally distributed. Data analysis in ArcMap 10.1 indicated that EC values of all wells in the study area during 2005 were not normally distributed (Fig. 15a). Thus, log transformation was applied to normalize the data, as illustrated in Fig. 15b, where the mean and median were almost equal.

In this study, Ordinary kriging was applied with two models: Spherical and Gaussian, and then the best-fit model was selected for each year. The Kriging methods have the advantage of minimizing the variance of errors compared to the Inverse Distance Weighting (IDW) method [28]. Al-Mashagbah, Al-Adamat, and Salameh [29] found that the ordinary kriging with different semi-variogram models was the best method for mapping groundwater quality parameters such as $\mathrm{Ca}^{2+}, \mathrm{Na}^{+}, \mathrm{Cl}^{-}$and $\mathrm{NO}_{3}{ }^{-}$. Gaussian and Spherical models were considered the best models for representing the groundwater quality parameters [30]. The best-fit model of interpolation was selected according to two criteria, namely, lowest RMSE and highest $\mathrm{R}^{2}$ [30, 31]. For EC data in 2005 , the best fit model was the spherical model ( $R M S E=3.84 \mathrm{dS} / \mathrm{m}, \mathrm{R}^{2}=0.618$ ) compared to the Gaussian model $\left(\mathrm{RMSE}=3.90 \mathrm{dS} / \mathrm{m}, \mathrm{R}^{2}=0.613\right.$ ). The spatial distribution of $\mathrm{GH}$ farms in 2008 overlaid on groundwater EC map of 2005 based on Ordinary Kriging is shown in Fig. 16. It is important to note that accurate interpolation of 
Asma M. Al-Maimani et al., 2019. Spatio-Temporal Distribution of Greenhouses and Affecting Driving Factors in Al-Batinah South, Oman, Using GIS Mapping / American-Eurasian Journal of Sustainable Agriculture. 13(2): 13-33. DOI: 10.22587/aejsa.2019.13.2.2

EC values was found near the coastline because all observation wells were located on coastline (Baka and AlMusannah), where less accuracy for inland areas (shaded lines).

For the period 2010-2016, the highest average inland creeping of seawater intrusion interface was 92 $\mathrm{m}$ /year in Bani Kharous catchment compared to other catchments [21] by considering the maximum distance of the salinity interface line of $10 \mathrm{dS} / \mathrm{m}$. Since the inland creeping of seawater intrusion was very small, matching the EC data in 2016 with the spatial distribution of GH farms in 2017 will not be a problem. Log transformation was applied to normalize the data for 2016, Fig 17. Gaussian model ( $R M S E=6.66 \mathrm{dS} / \mathrm{m}, \mathrm{R}^{2}=0.547$ ) was the best-fit model for 2016 groundwater EC data as compared to the Spherical model (RMSE=6.71 dS/m, $\left.\mathrm{R}^{2}=0.544\right)$.

Figure 18 depicts the spatial distribution of GH farms in 2017 about groundwater EC data in the study area. From Fig. 16 and Fig. 18, groundwater salinity near the coastline was very high (> 3dS/m), i.e., unsuitable for $\mathrm{GH}$ farm construction, compared to inland areas with lower groundwater salinity $(<3 \mathrm{dS} / \mathrm{m})$. Nevertheless, the effect of groundwater salinity on the spatial distribution of GH farms in 2017 was found to be statistically insignificant $(\mathrm{p}>0.05)$. Overall, $\mathrm{GH}$ farms $(\%)$ in areas with high levels of groundwater salinity showed, as expected, a decreasing trend $\left(\mathrm{R}^{2}=0.69\right)$, Fig. 19. This means that farmers started realizing the importance of constructing $\mathrm{GH}$ farms in areas having suitable groundwater quality.

\section{The effect of nearness to the coastline}

For the distribution of $\mathrm{GH}$ farms relative to the coastline, results revealed the statistically insignificant influence of distance from the coastline on the spatial distribution of GH farms (\%) in the study area $\left(\mathrm{p}>0.05, \mathrm{R}^{2}\right.$ $=0.248)$, Fig. 20. There was an overall decreasing trend of GH farms (\%) with distance from the coastline (Barka and Al-Musannah) towards the inland. This trend was unaccepted because about $58 \%$ of GH farms were located in profoundly affected areas with groundwater salinity near the coastline. This could be because most of these farms were inherited from parents [32] and groundwater deterioration due to seawater intrusion took place afterward. Therefore, it was not easy for the farmers to sell or shift the locations of their farms, and it takes time for decision making. Thus, many farmers started to adapt to seawater intrusion by installing on-farm desalination units.

For 2017, two peaks of GH farms densities were found near the coastline; one was within 0-5 km, and the other one was within 5-10 km from the coastline, Fig. 21. About 12.9\% (11/85) of GH farms were located within $0-5 \mathrm{~km}$ of which $72.7 \%$ of these farms $(8 / 11)$ had small-scale desalination units to meet the optimal water quality for plant growth. On the other hand, nearly $57.6 \%$ of GH farms (49/85) were located within 5-10 km from the coastline of which $22.4 \%$ (11/49 farm) of these farms were using irrigation water from small-scale desalination plants. Finally, only $29.4 \%$ of GH farms were located within $10-70 \mathrm{~km}$ from the coastline where the desalination plants were not in-use because the groundwater quality was improving inland, Fig. 18. Therefore, it is highly recommended to consider areas with low groundwater salinity for $\mathrm{GH}$ farms to reduce the cost of desalination units.

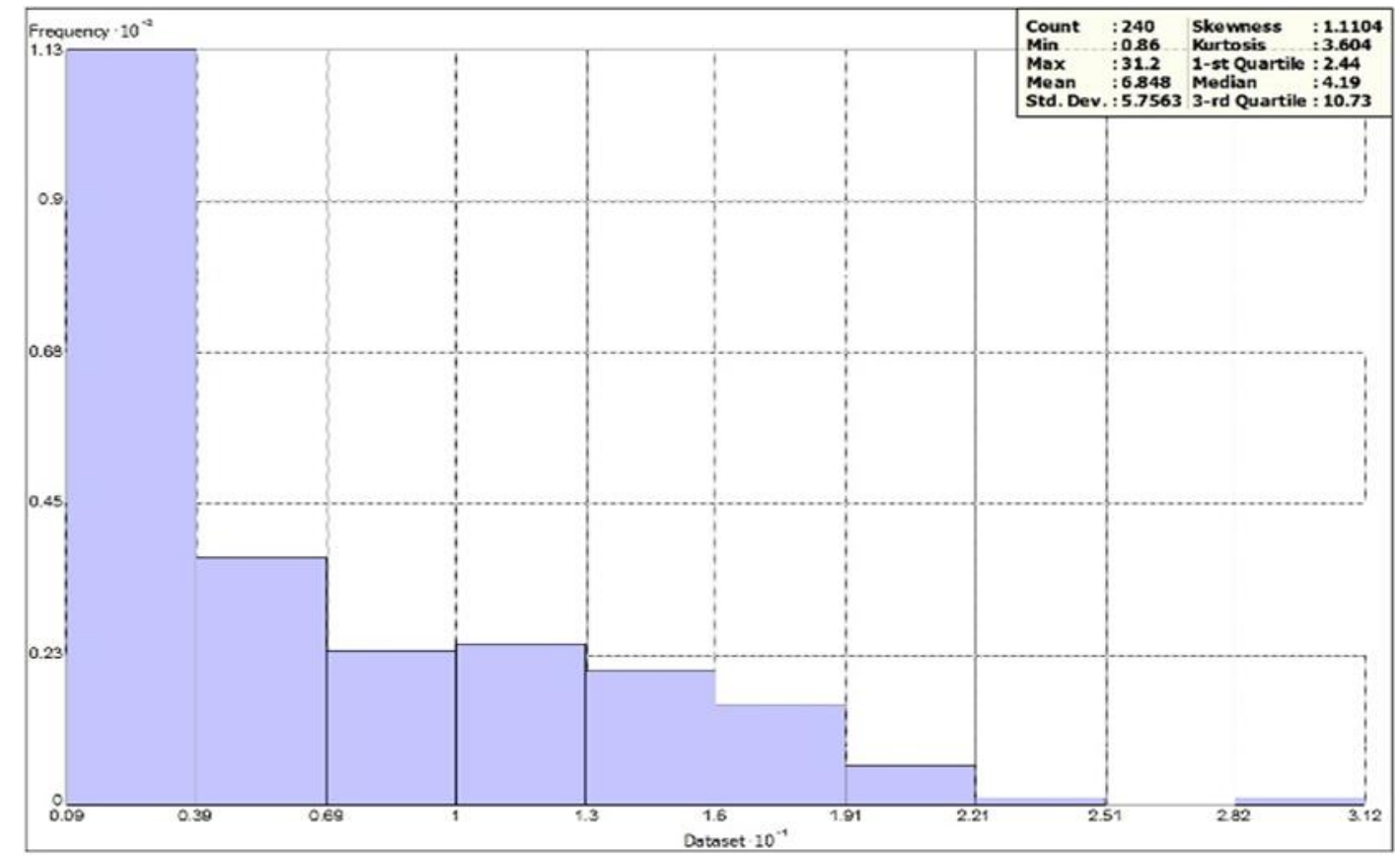

(a) 
Asma M. Al-Maimani et al., 2019. Spatio-Temporal Distribution of Greenhouses and Affecting Driving Factors in Al-Batinah South, Oman, Using GIS Mapping / American-Eurasian Journal of Sustainable Agriculture. 13(2): 13-33. DOI: 10.22587/aejsa.2019.13.2.2

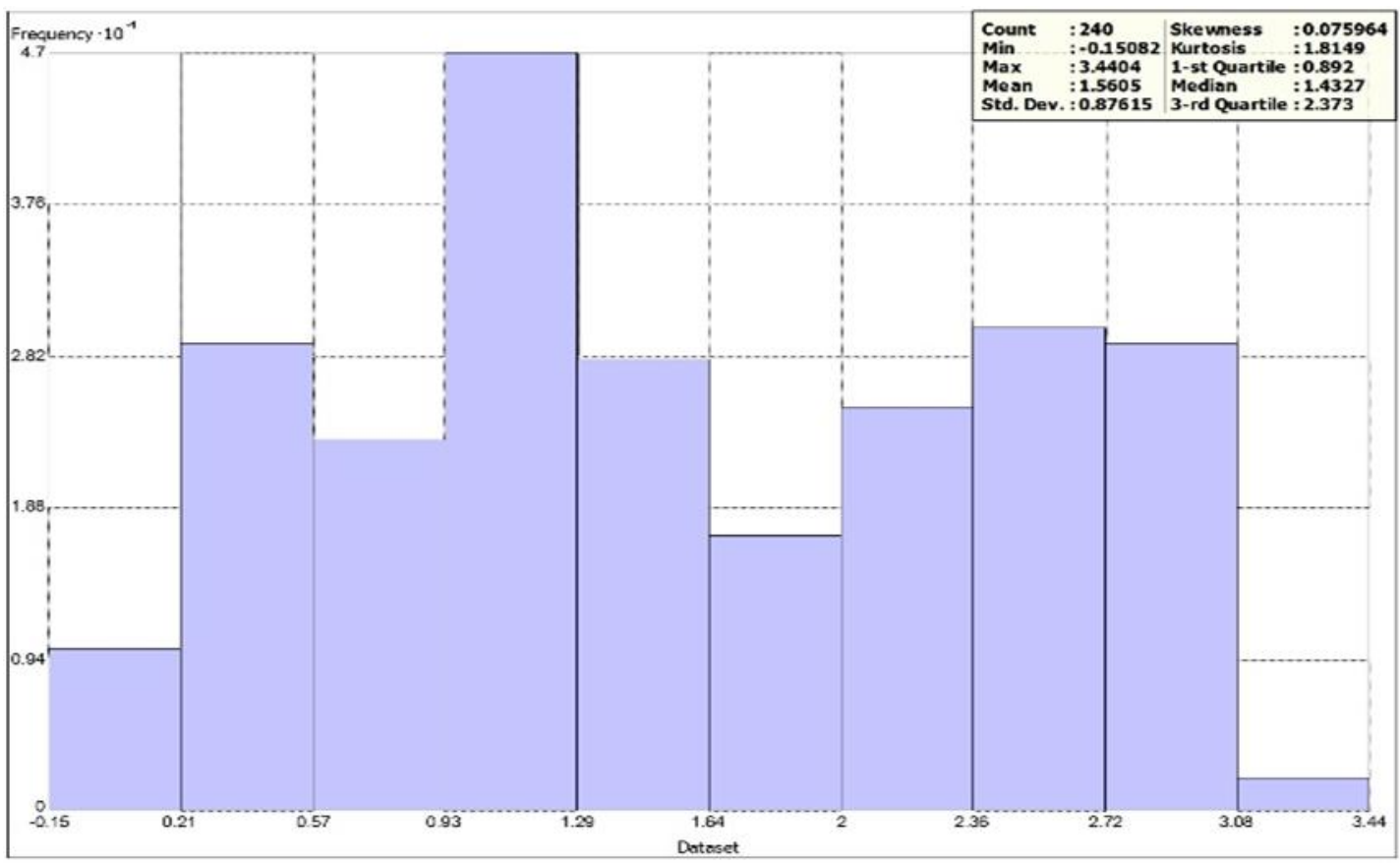

(b)

Figure 15: Histogram of (a) EC and (b) log EC in 2005

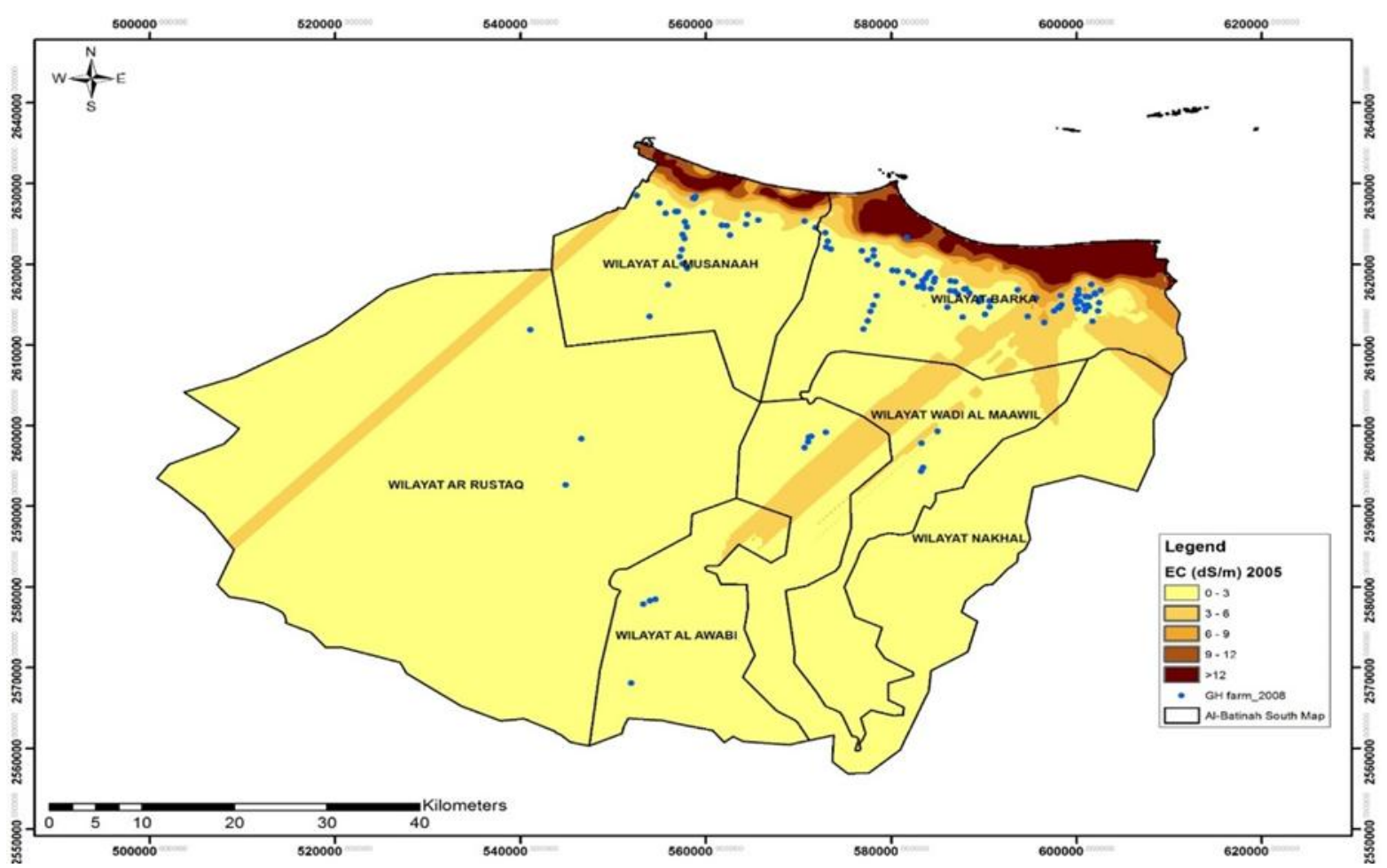

Figure 16: Spatial distribution of GH farms in 2008 using EC values in 2005 based on Kriging method

In the period 2008-2017, the overall changes in the number of GH farms from the coastline at $5 \mathrm{~km}$ intervals are given in Fig. 22. The average change in a number of GH farms was negative between $0-25 \mathrm{~km}$ from the coastline, except at $0-5 \mathrm{~km}$. Afterward, there was an overall positive average change in the number of GH farms. In general, the number of GH farms was decreasing in the area close to the coastline and increasing in the area away from the coastline. This could be attributed to the realization of farmers to the importance of 
Asma M. Al-Maimani et al., 2019. Spatio-Temporal Distribution of Greenhouses and Affecting Driving Factors in Al-Batinah South, Oman, Using GIS Mapping / American-Eurasian Journal of Sustainable Agriculture. 13(2): 13-33. DOI: $10.22587 /$ aejsa.2019.13.2.2

building GHs in areas having good groundwater quality. Similarly, Yu, Song, and Lang [10] found that the decline in GH-occupied lands towards the coastline was driven by the soil salinity in Shouguang, China.

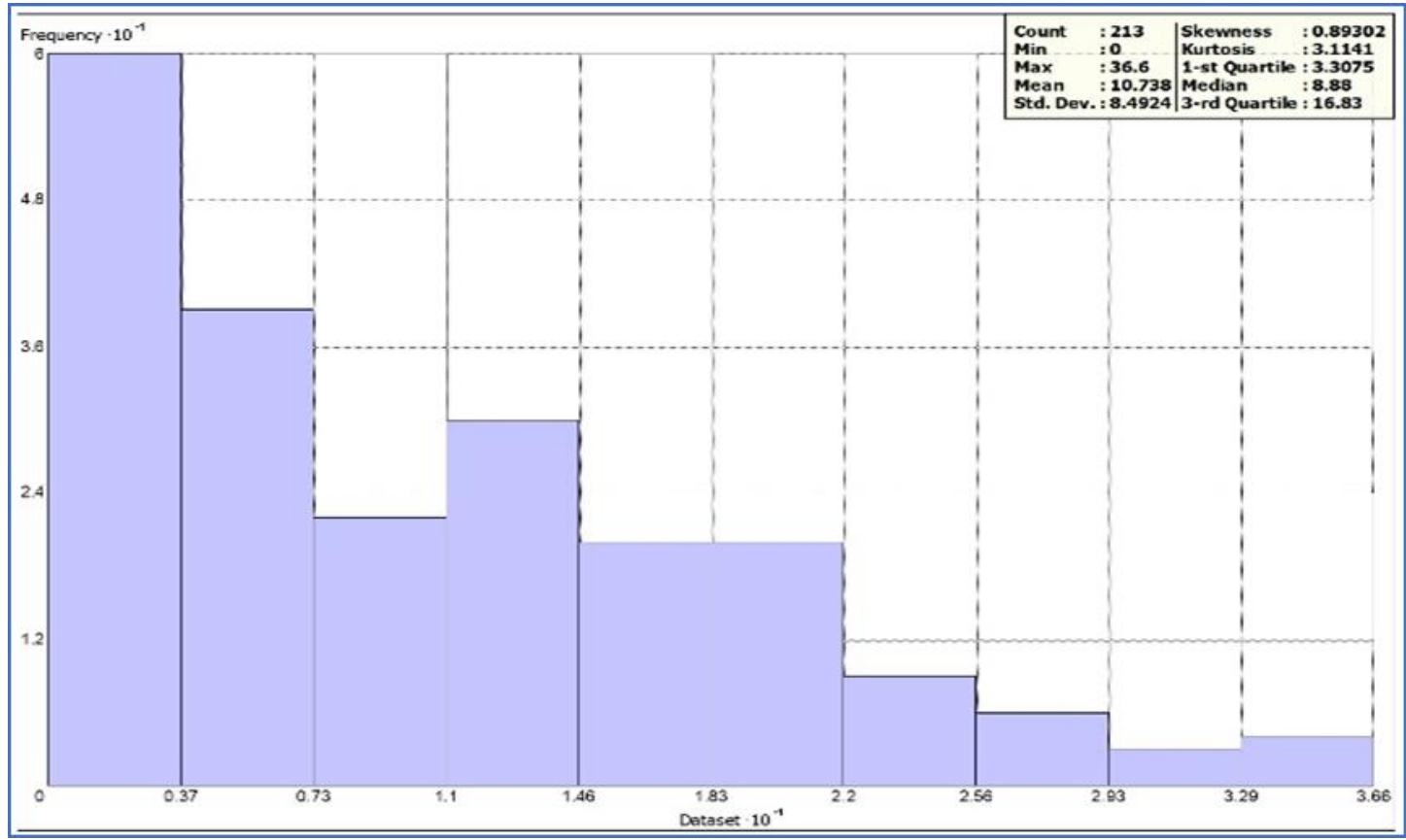

(a)

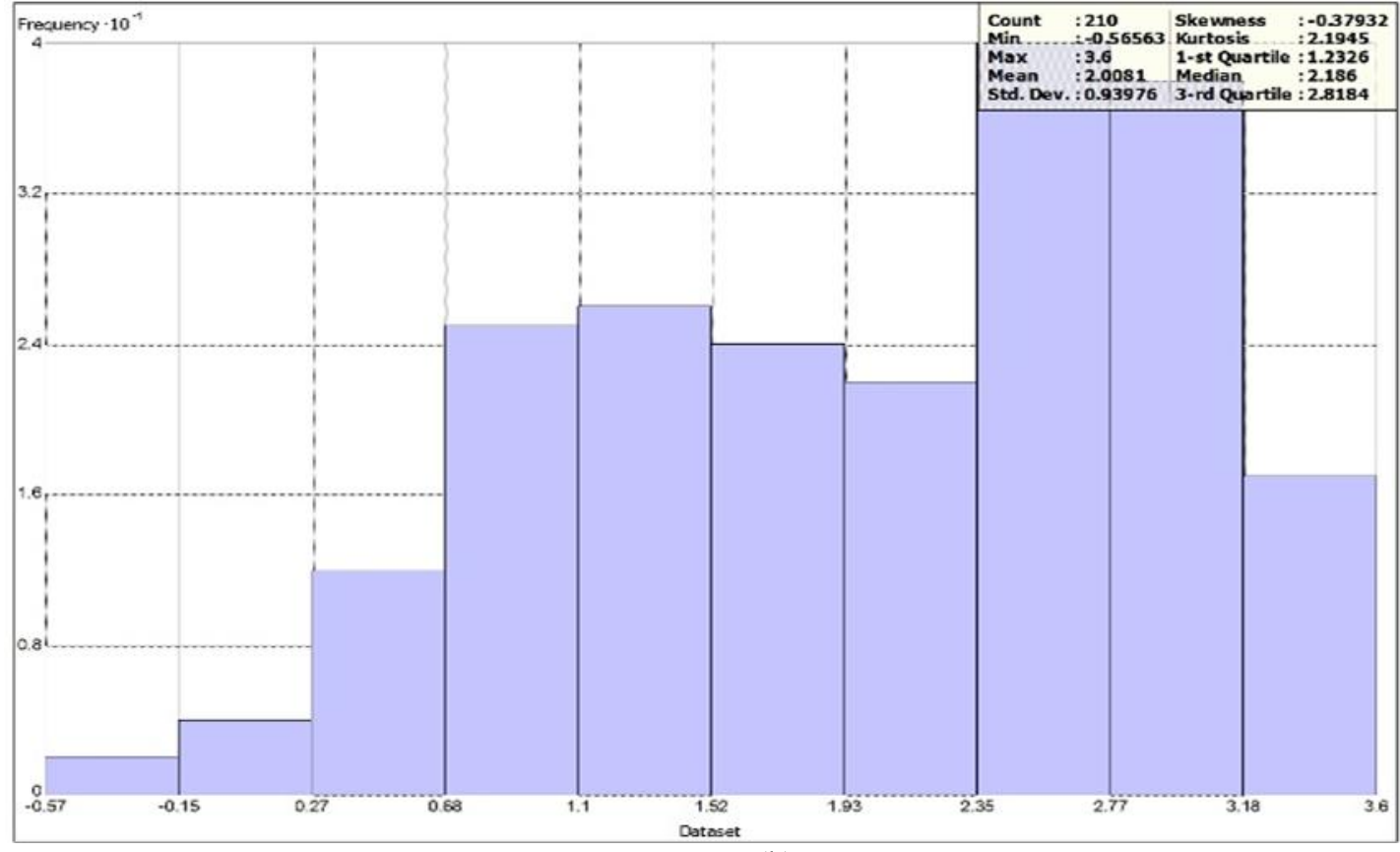

(b)

Figure 17: Histograms of (a) EC and (b) $\log$ EC in 2016 
Asma M. Al-Maimani et al., 2019. Spatio-Temporal Distribution of Greenhouses and Affecting Driving Factors in Al-Batinah South, Oman, Using GIS Mapping / American-Eurasian Journal of Sustainable Agriculture. 13(2): 13-33. DOI: $10.22587 /$ aejsa.2019.13.2.2

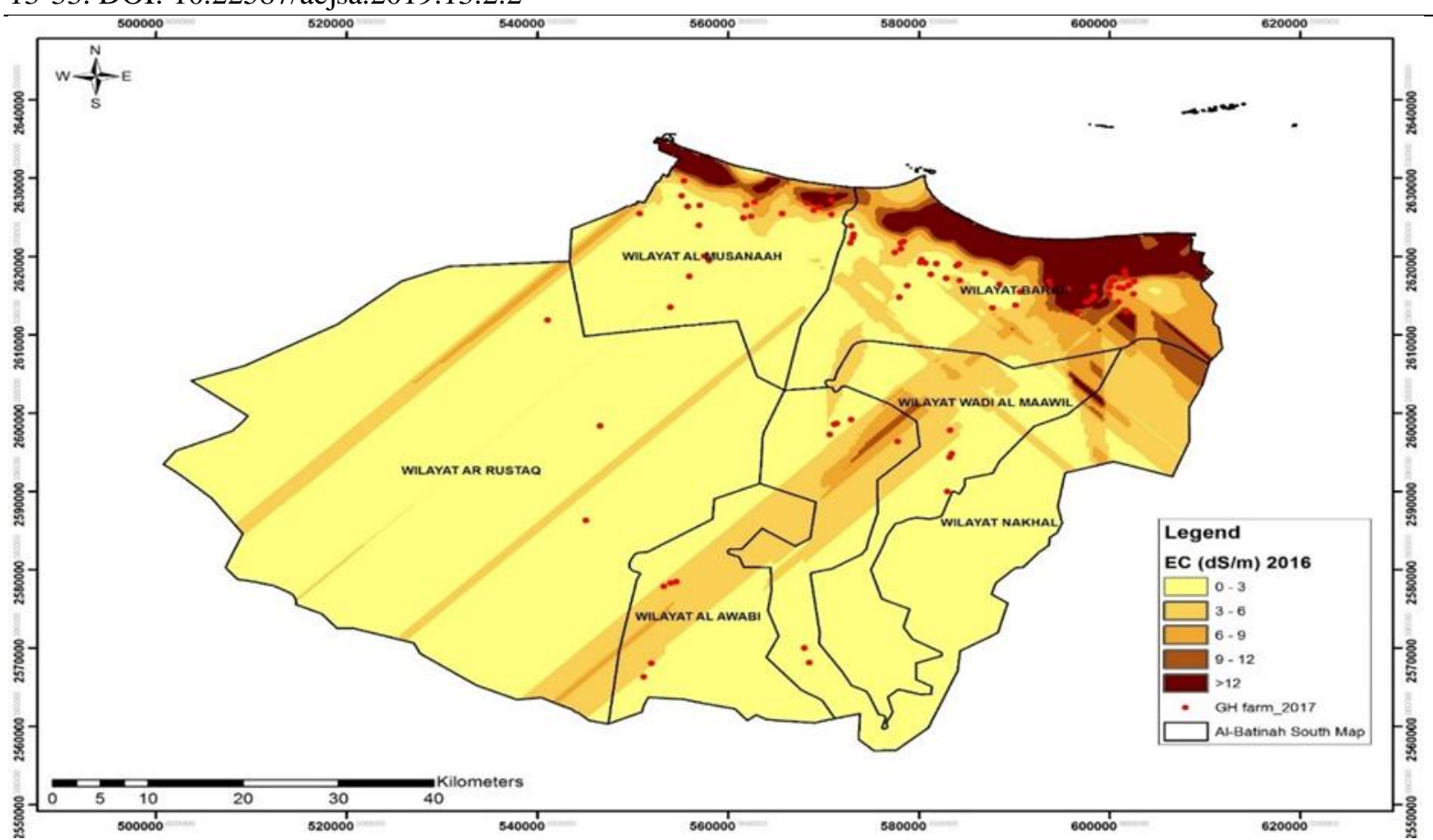

Figure 18: Spatial distribution of GH farms in 2017 and EC in 2016 from the Kriging method

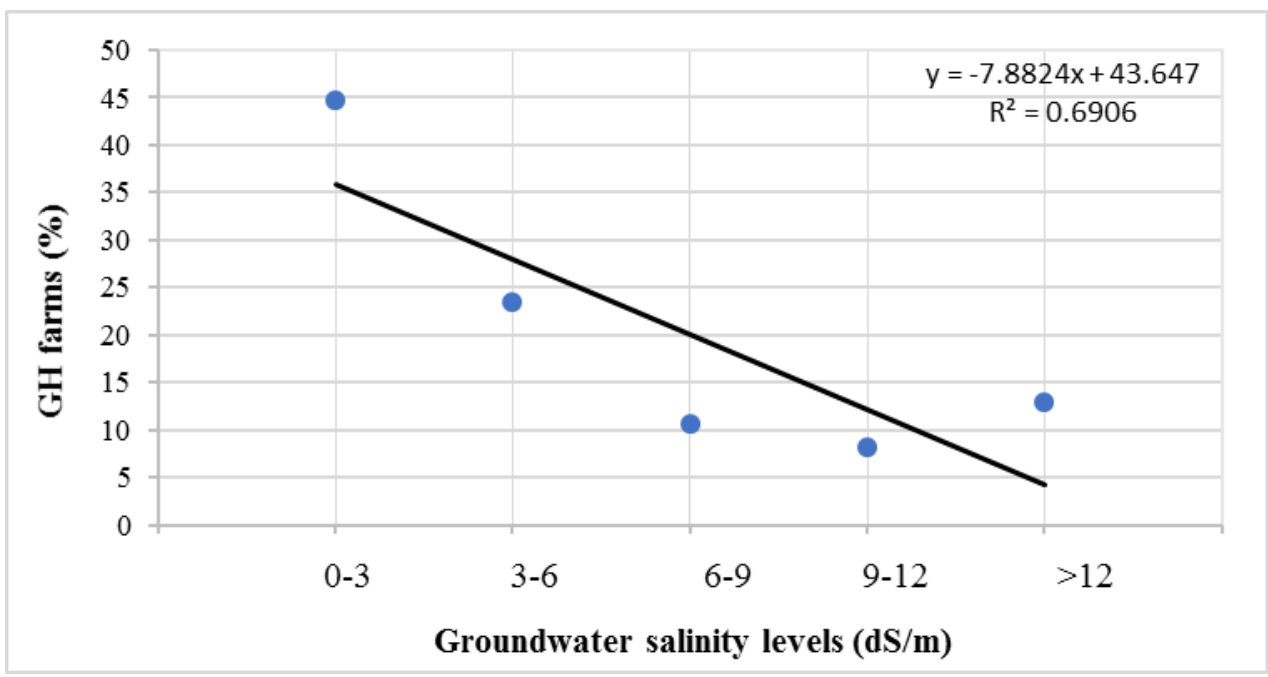

Figure 19: The distribution of GH farms with levels of groundwater salinity 
Asma M. Al-Maimani et al., 2019. Spatio-Temporal Distribution of Greenhouses and Affecting Driving Factors in Al-Batinah South, Oman, Using GIS Mapping / American-Eurasian Journal of Sustainable Agriculture. 13(2): 13-33. DOI: 10.22587/aejsa.2019.13.2.2

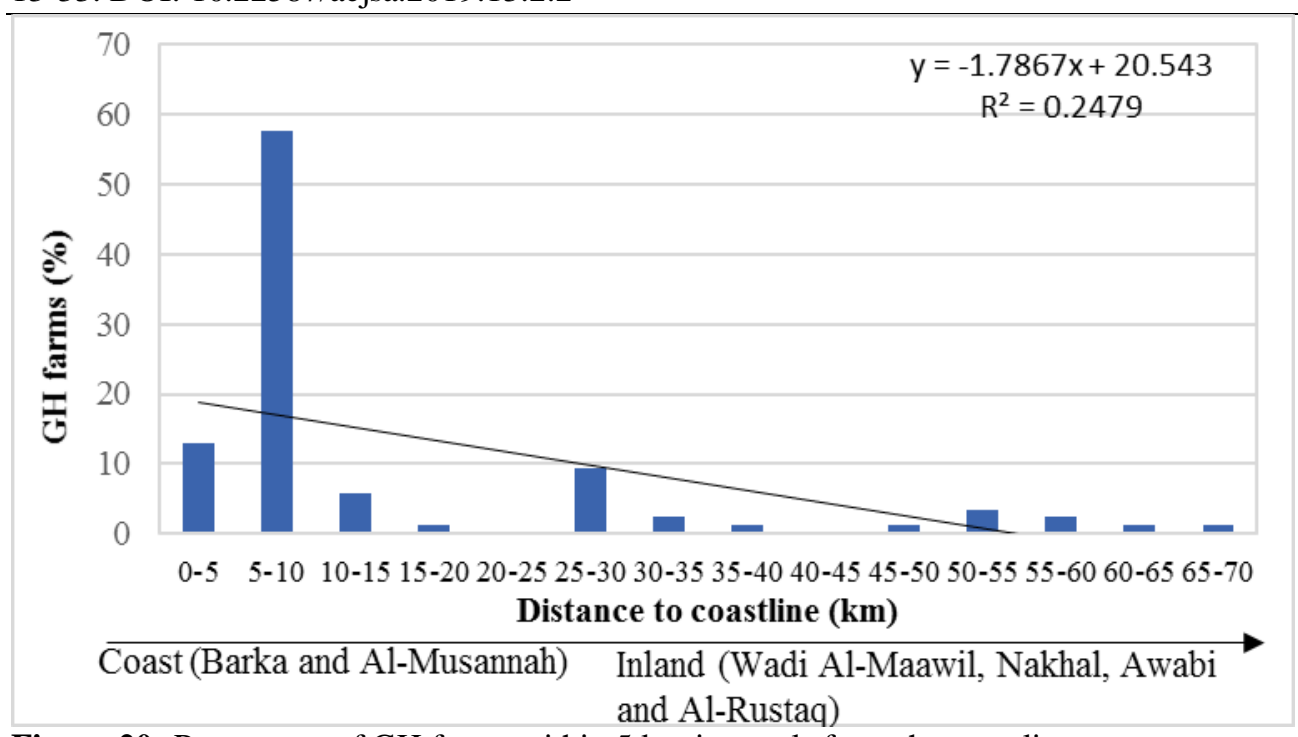

Figure 20: Percentage of GH farms within $5 \mathrm{~km}$ intervals from the coastline

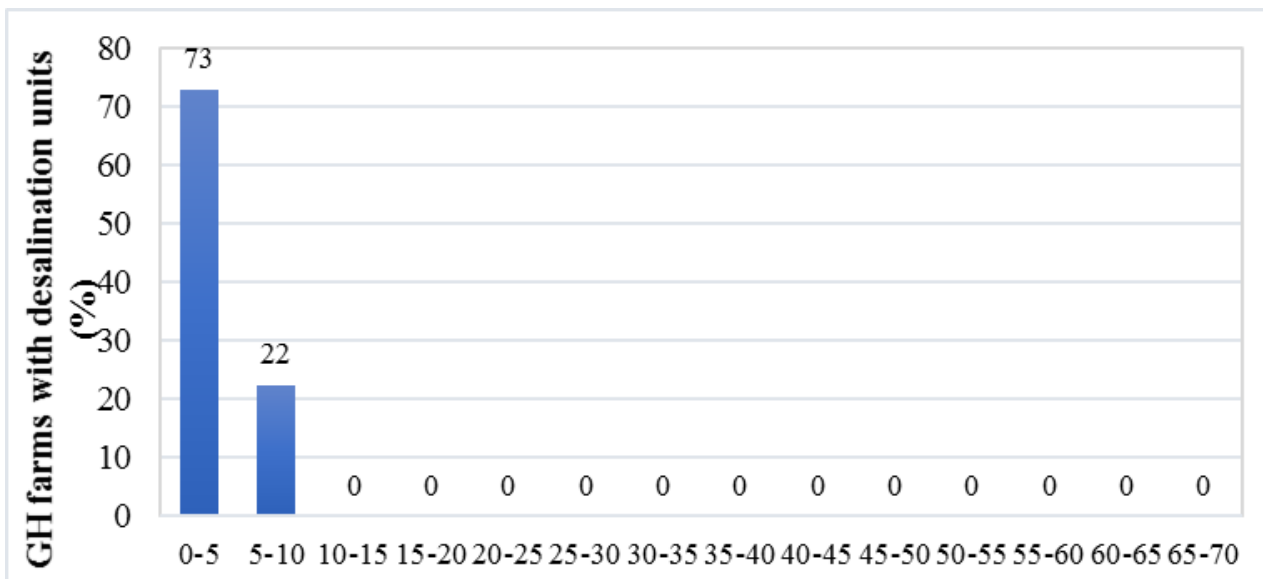

Distance to coastline $(\mathrm{km})$

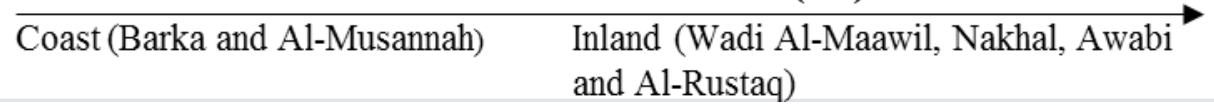

Figure 21: Percentage of GH farms having desalination units in each $5 \mathrm{~km}$ intervals from the coastline

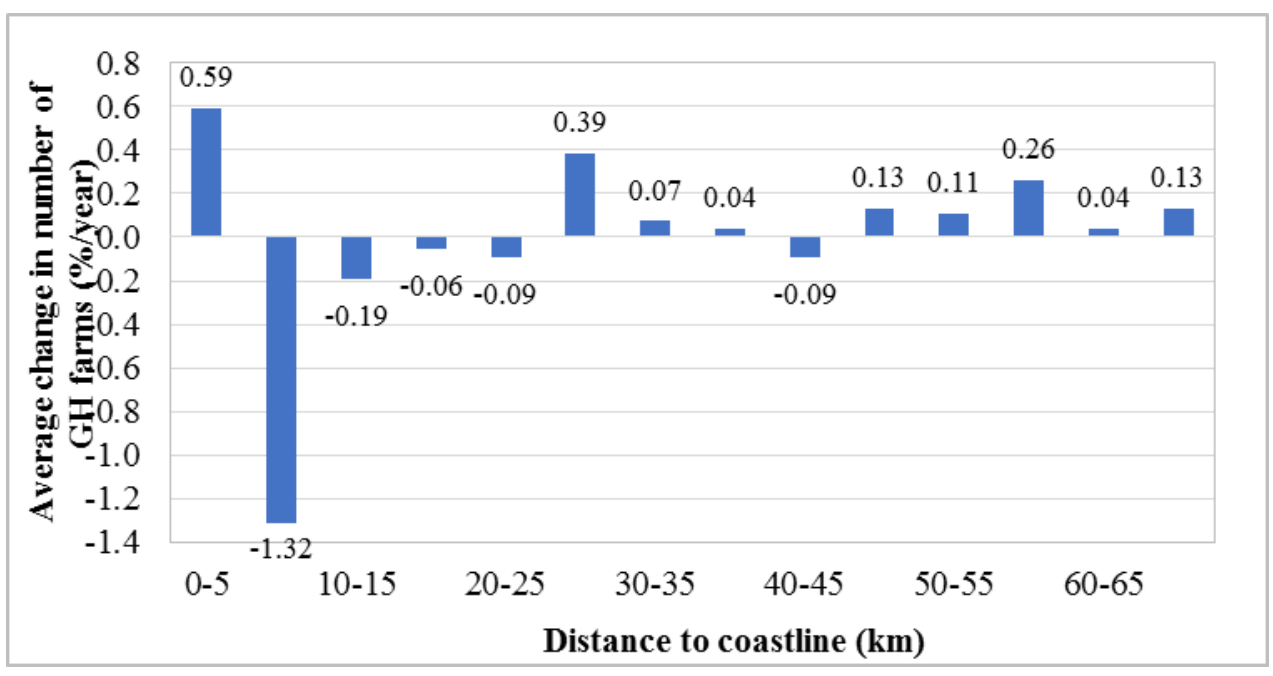


Asma M. Al-Maimani et al., 2019. Spatio-Temporal Distribution of Greenhouses and Affecting Driving Factors in Al-Batinah South, Oman, Using GIS Mapping / American-Eurasian Journal of Sustainable Agriculture. 13(2): 13-33. DOI: 10.22587/aejsa.2019.13.2.2

Figure 22: The average changes in number of GH farms from the coastline at $5 \mathrm{~km}$ intervals during the study period: 2008-2017

\section{The effect of nearness to roads}

The proximity of farms to paved roads could offer faster access to the main roads and thus to market outlets. Results showed that the distribution of GH farms (\%)about the distance to the highway in Al-Batinah South was statistically significant $(\mathrm{p}<0.05)$. About $70 \%$ of $\mathrm{GH}$ farms were located within $0-5 \mathrm{~km}$ from the highway. This could be attributed to the development of road network in the study area over the last years or due to the recognition of farmers of the importance to construct GHs near significant roads for easier transportation of produce. Although there was an overall decreasing trend of GH farms (\%) with increasing distance from the highway, the correlation between the distribution and the distance from the highway was not very robust $\left(\mathrm{R}^{2}=0.511\right)$, Fig. 23. The distribution of GH farms about all paved roads in Al-Batinah South is illustrated in Fig. 24. The results showed that statistically significant influence of GH farms (\%) with relation to the nearest paved road $(\mathrm{p}<0.05)$. This is reflected with the decreasing percentage of GH farms with distance from nearest paved roads $\left(\mathrm{R}^{2}=0.751\right)$, Fig. 25 . Most of GH farms $(>50 \%)$ were located within $1 \mathrm{~km}$ from the nearest paved road. Therefore, the effect of proximity to the highway and paved roads was significant in the spatial distribution of GH farms in this study. Similarly, it was found that the proximity to the highway and nearest paved roads had significant effects in the contraction of lands occupied by GHs in Shouguang, China [10]. In contrast, Justus and $\mathrm{Yu}$ [20] found that road density was insignificant in predicting the spatial distribution of GH farms among watersheds in Kenya.

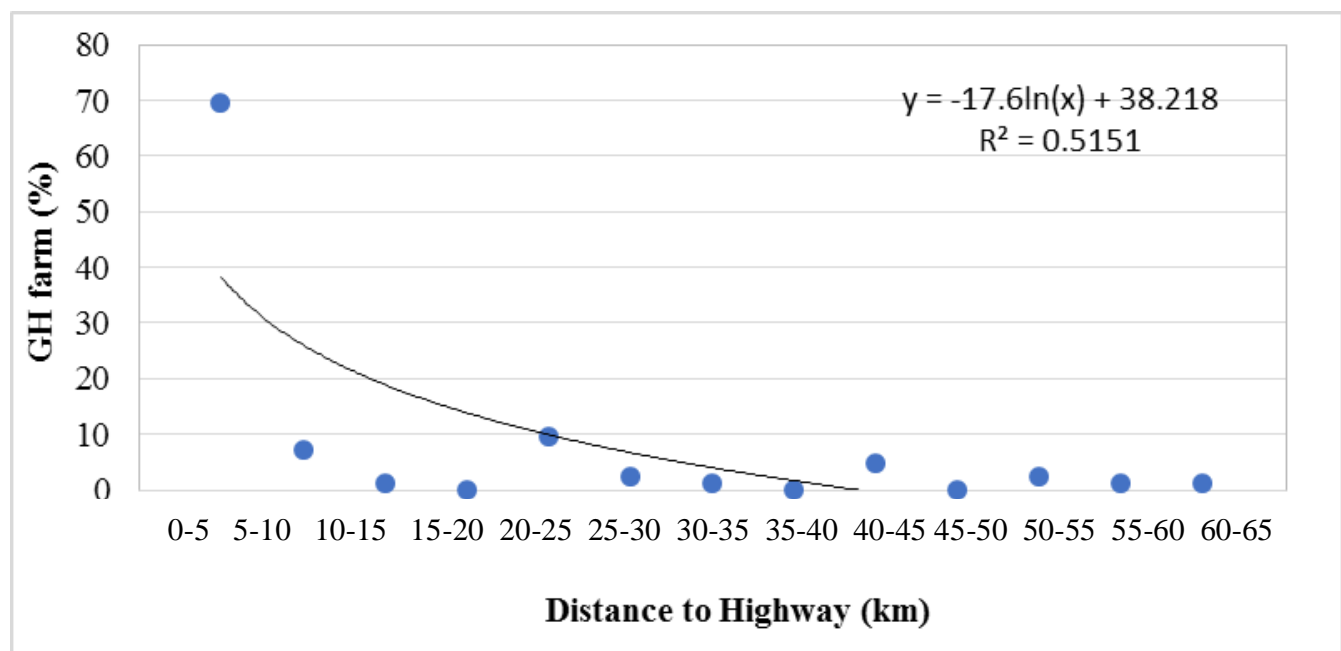

Figure 23: The percentage of GH farms at $5 \mathrm{~km}$ intervals from the highway in Al-Batinah South 
Asma M. Al-Maimani et al., 2019. Spatio-Temporal Distribution of Greenhouses and Affecting Driving Factors in Al-Batinah South, Oman, Using GIS Mapping / American-Eurasian Journal of Sustainable Agriculture. 13(2): 13-33. DOI: 10.22587/aejsa.2019.13.2.2

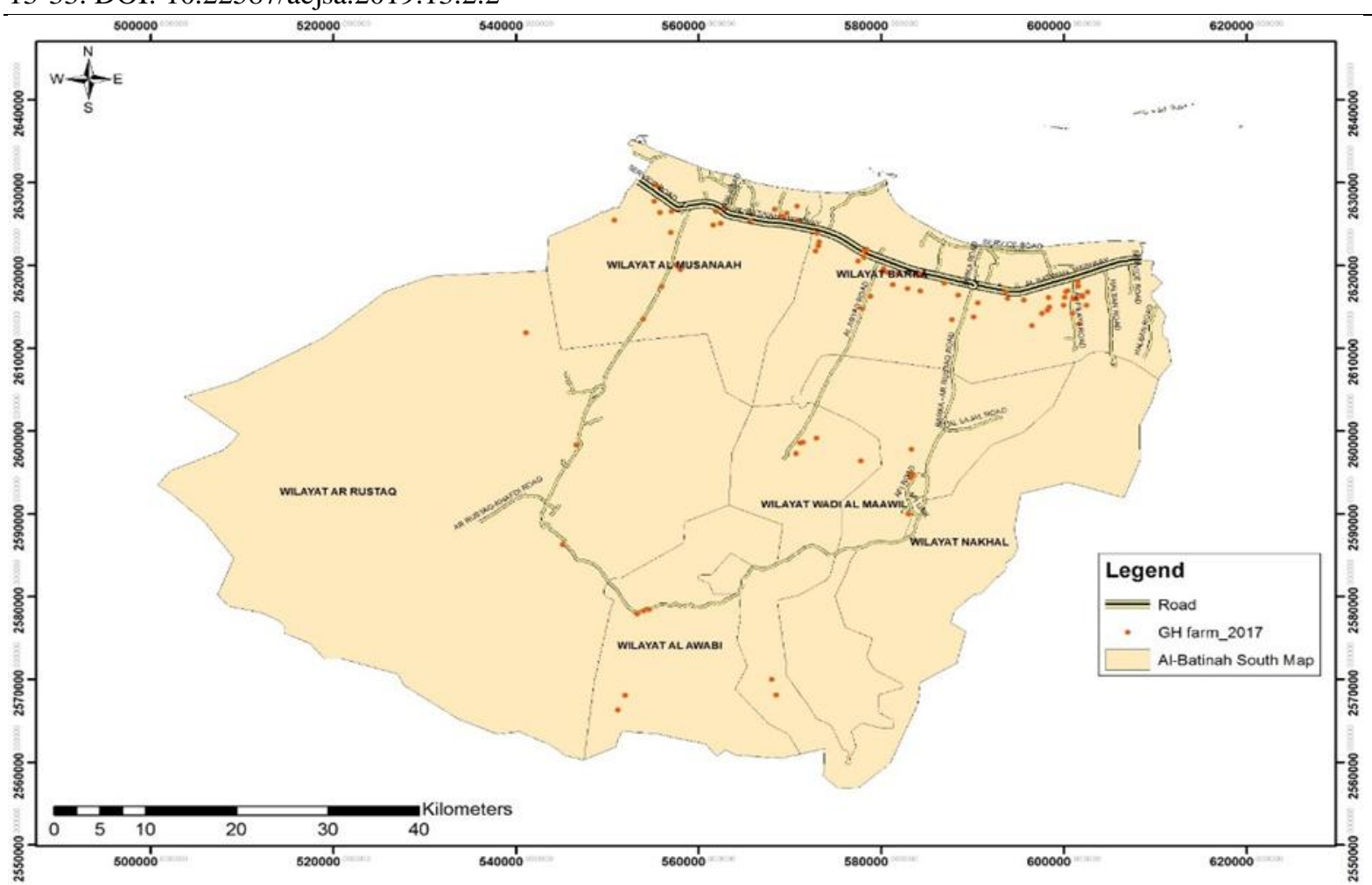

Figure 24: Distribution of GH farms in relation to paved roads in Al-Batinah South

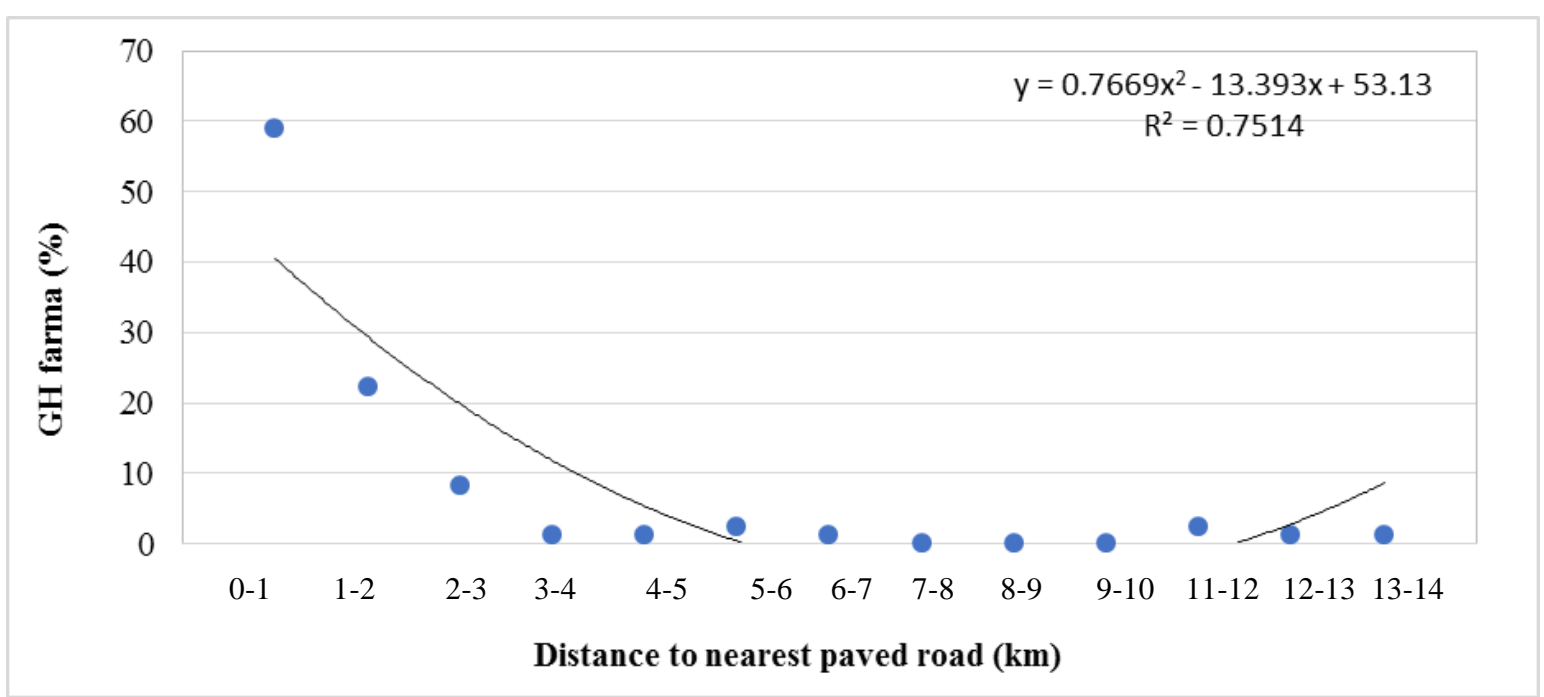

Figure 25: The percentage of GH farms at $1 \mathrm{~km}$ intervals from the nearest paved road in Al-Batinah South

\section{The most affecting driving factors for GH farms distribution using PCA analysis}

PCA was applied to the aforementioned driving factors: distance to local markets, distance to Al-Mawaleh central market, distance to the highway, distance to the nearest paved road, distance to coastline and groundwater salinity levels at GH farm level in order to evaluate the most driving factors contributing to the spatial distribution of GH farms in 2017. The results revealed that there were only two driving factors affecting the spatial distribution of GH farms in 2017 by their contribution to the total variance of the distribution. The distance to local markets and Al-Mawaleh central market were the most contributing factors in the total variance of the spatial distribution of GH farms (44.3\% and $23.8 \%$, respectively), Table 3 . The remaining driving factors were not significant in describing the variance of the spatial distribution of GH farms. 
Asma M. Al-Maimani et al., 2019. Spatio-Temporal Distribution of Greenhouses and Affecting Driving Factors in Al-Batinah South, Oman, Using GIS Mapping / American-Eurasian Journal of Sustainable Agriculture. 13(2): 13-33. DOI: 10.22587/aejsa.2019.13.2.2

\begin{tabular}{|c|c|c|c|c|c|c|}
\hline \multicolumn{7}{|c|}{ Table 3: Total variance analyzed using PCA } \\
\hline \multirow{2}{*}{ Component } & \multicolumn{3}{|c|}{ Initial Eigen values } & \multicolumn{3}{|c|}{$\begin{array}{c}\text { Extraction Sums of Squared } \\
\text { Loadings }\end{array}$} \\
\hline & Total & $\begin{array}{c}\text { \% of } \\
\text { Variance }\end{array}$ & $\underset{\%}{\text { Cumulative }}$ & Total & $\begin{array}{c}\% \text { of } \\
\text { Variance }\end{array}$ & $\underset{\%}{\text { Cumulative }}$ \\
\hline $\begin{array}{l}1 \text { (Distance to local } \\
\text { markets) }\end{array}$ & 2.657 & 44.276 & 44.276 & 2.657 & 44.276 & 44.276 \\
\hline $\begin{array}{c}2 \text { (Distance to central } \\
\text { market) }\end{array}$ & 1.430 & 23.830 & 68.106 & 1.430 & 23.830 & 68.106 \\
\hline 3 (Distance to Highway) & 0.747 & 12.450 & 80.556 & & & \\
\hline $\begin{array}{l}4 \text { (Distance to nearest } \\
\text { paved road) }\end{array}$ & 0.722 & 12.035 & 92.591 & & & \\
\hline 5 (Distance to coastline) & 0.443 & 7.375 & 99.967 & & & \\
\hline $\begin{array}{c}6 \text { (Effect of groundwater } \\
\text { level) }\end{array}$ & 0.002 & 0.033 & 100.000 & & & \\
\hline
\end{tabular}

\section{CONCLUSION}

In this study, GIS mapping was used to map and identify the influence of four driving factors on the spatiotemporal distribution of greenhouses (GHs) in Al-Batinah South Governorate, Oman. For 2017, the spatial distribution of GH farms and GHs varied insignificantly among the six cities in Al-Batinah South. The city of Barka had the highest density of GH farms, and GHs and Al-Rustaq had the least number. GH farms spatial distribution showed that most of GHs were concentrated in a strip of land 5-10 km from the coastline and a less density of GH farms was noticed in the central part of Al-Batinah South. For 2008, a similar GH farms distribution pattern was observed. Over the period 2008-2017, there was an overall decrease in the average number of GH farms and GHs due to land use changes, high construction costs (capital cost), high production costs (e.g. seed, fertilizers and pests), fuel cost, pests and diseases, water scarcity (in some places), competition due to foreign produce and from high tech domestic and foreign competitor problem, low subsidy by MAF and/or price fluctuations of fresh produce.

The influence of distance to local markets, distance to Al-Mawaleh central market, groundwater salinity and distance from the coastline on the spatial distribution of GH farms was statistically insignificant. However, the influence of distance to the highway and distance to the nearest paved roads were found significant driving factors $(\mathrm{p}<0.05)$. Based on Principle Component Analysis (PCA), distance to local markets and distance to AlMawaleh Central market were the two driving factors describing the total variance of spatial distribution of GH farms. At the end of this study, it is highly recommended for future expansion of GH farms to take in consideration the inland areas with low groundwater salinity for GHs construction in order to reduce the cost of desalination units. Moreover, other driving factors such as soil parameters (type, pH, EC, cation exchange capacity and exchangeable sodium), topographic (average bedrock and elevation), distance to urban settlements, road density and population density should be further studied to examine their significance on the spatial distribution of $\mathrm{GH}$ farms and GHs.

\section{ACKNOWLEDGMENT}

Authors would like to express their sincere thanks to The Research Council, Oman for funding this work through an open grant research fund (project code: RC/AGR/SWAE/15/01).

\section{FUNDING}

This work received a research fund from The Research Council, Oman through project number RC/AGR/SWAE/15/01.

\section{REFERENCES}

[1] Ahmed, M., Hussain, N. and Al-Rawahy, S.A. (2013). Management of saline lands in Oman: Learning to live with salinity, Developments in soil salinity assessment and reclamation, Springer, pp. 265-281.

[2] Hussian, N., Al-Rawahy, S.A., Rabee, J. and Al-Amri, M. (2006). Causes, origin, genesis and extent of soil salinity in the Sultanate of Oman. Pak. J. Agri. Sci, 43: 1-2.

[3] Choudri, B.S., Baawain, M., Ahmed, M., Al-Sidairi, A. and Al-Nadabi, H. (2015). Relative vulnerability of coastal Wilayats to development: a study of Al-Batinah North, Oman. Journal of Coastal Conservation, 19: 51-57.

[4] MRMWR. (2016). Water Resources Development, Ministry of Regional Municipalities and Water Resources, Muscat, Oman. 
Asma M. Al-Maimani et al., 2019. Spatio-Temporal Distribution of Greenhouses and Affecting Driving Factors in Al-Batinah South, Oman, Using GIS Mapping / American-Eurasian Journal of Sustainable Agriculture. 13(2): 13-33. DOI: 10.22587/aejsa.2019.13.2.2

[5] MAF and ICARDA. (2011). Assessing returns to support investments in two agricultural development projects (protected agriculture and modern irrigation systems) in the Sultanate of Oman, Final report.

[6] Al-Ismaili, A.M. and Jayasuriya, H. (2016). Seawater greenhouse in Oman: A sustainable technique for freshwater conservation and production. Renewable and Sustainable Energy Reviews, 54: 653-664.

[7] Kumar, K.S., Tiwari, K.N. and Jha, M.K. (2009). Design and technology for greenhouse cooling in tropical and subtropical regions: A review. Energy and Buildings, 41: 1269-1275.

[8] Al-Ismaili, A.M., Al-Mezeini, N.K. and Jayasuriya, P.H. (2017). Controlled Environment Agriculture in Oman: Facts and Mechanization Potentials. Agricultural Mechanization in Asia, Africa and Latin America, 48: 45-51.

[9] MAF. (2013). Agricultural Census Report 2012/2013 Ministry of Agricultural and Fisheries, Muscat, Oman.

[10] Yu, B., Song, W. and Lang, Y. (2017). Spatial Patterns and Driving Forces of Greenhouse Land Change in Shouguang City, China. Sustainability, 9: 359.

[11] Agüera, F. and Liu, J.G. (2009). Automatic greenhouse delineation from QuickBird and Ikonos satellite images. Computers and Electronics in Agriculture, 66: 191-200.

[12] Crifasi, G., Grassa, F. and Scrofani, M. (2002). Validity of geographic information systems (GIS) applied to protected cultivations, VI International Symposium on Protected Cultivation in Mild Winter Climate: Product and Process Innovation 614, pp. 41-46.

[13] Deadman, M.L., Al-Sadi, A.M., Al-Wardi, M.M., Al-Kiyumi, K.S.M., Deadman, W.M. and Al Said, F.A. (2016). Spatio-temporal dynamics of land use changes in response to external pressures in Oman: Greenhouse cropping as an example. Journal of Agricultural and Marine Sciences, 21: 33 - 46.

[14] Sajjad, A., Hussain, A., Wahab, U., Adnan, S., Ali, S., Ahmad, Z. and Ali, A. (2015). Application of Remote Sensing and GIS in Forest Cover Change in Tehsil Barawal, District Dir, Pakistan. American Journal of Plant Sciences, 6: 1501.

[15] Sönmez, N.K. and Mustafa, S. (2006). Use of remote sensing and geographic information system technologies for developing greenhouse databases. Turkish journal of agriculture and forestry, 30: 413-420.

[16] Picuno, P., Tortora, A. and Capobianco, R.L. (2011). Analysis of plasticulture landscapes in Southern Italy through remote sensing and solid modelling techniques. Landscape and Urban Planning, 100: 45-56.

[17] Al-Alawi, M. (2015). No. of constructed Controlled Environment Agriculture (CEA) in all the governorates in the Sultanate, MAF.

[18] MAF. (2009). Technical extension guide of controlled environment agriculture technologies in Oman, Ministry of Agriculture and Fisheries, Muscat, Oman.

[19] Castilla, N., Baeza, E. and Papadopoulos, A.P. (2012), Marketing, Greenhouse technology and management, Cabi, UK, pp. 1-335.

[20] Justus, F. and Yu, D. (2014). Spatial distribution of greenhouse commercial horticulture in Kenya and the role of demographic, infrastructure and topo-edaphic factors. ISPRS International Journal of GeoInformation, 3: 274-296.

[21] MRMWR. (2017). Electrical conductivity of observation wells, salinity interface and catchmnets in AlBatinah South, Ministry of Regional Municipalities and Water Resources, Muscat, Oman.

[22] Petrişor, A.-I., Ianoş, I., Iurea, D. and Văidianu, M.-N. (2012). Applications of principal component analysis integrated with GIS. Procedia Environmental Sciences, 14: 247-256.

[23] Al-Ismaily, S. and Al-Maktoumi, A. (2011). Studying soil catena in arid-zone environment: Case study for soil science students. Atlas Journal of Science Education, 1: 24-28.

[24] Al-Kiyumi, K.S.M. (2009). Greenhouse cucumber production systems in Oman: A study on the effects of cultivation practices on crop diseases and crop yields., University of Reading.

[25] Maeda, E.E., Clark, B.J.F., Pellikka, P. and Siljander, M. (2010). Modelling agricultural expansion in Kenya's Eastern Arc Mountains biodiversity hotspot. Agricultural Systems, 103: 609-620.

[26] Dong, G., Xu, E. and Zhang, H. (2015). Spatiotemporal Variation of Driving Forces for Settlement Expansion in Different Types of Counties. Sustainability, 8: 39.

[27] Ayers, R.S. and Westcot, D.W. (1985). Water quality for agriculture, Food and Agriculture Organization of the United Nations Rome.

[28] Mehrjardi, R.T., Jahromi, M.Z., Mahmodi, S. and Heidari, A. (2008). Spatial distribution of groundwater quality with geostatistics (case study: Yazd-Ardakan Plain). World Applied Sciences Journal, 4: 9-17.

[29] Al-Mashagbah, A., Al-Adamat, R. and Salameh, E. (2012). The use of kriging techniques with in GIS environment to investigate groundwater quality in the Amman-Zarqa Basin/Jordan. Research Journal of Environmental and Earth Sciences, 4: 177-185. 
Asma M. Al-Maimani et al., 2019. Spatio-Temporal Distribution of Greenhouses and Affecting Driving Factors in Al-Batinah South, Oman, Using GIS Mapping / American-Eurasian Journal of Sustainable Agriculture. 13(2): 13-33. DOI: 10.22587/aejsa.2019.13.2.2

[30] Boufekane, A. and Saighi, O. (2016). Kriging method of study of the groundwater quality used for irrigation-case of Wadi Djendjen plain (North-East Algeria). Journal of Fundamental and Applied Sciences, 8: 346-362.

[31] Bhunia, G.S., Shit, P.K. and Maiti, R. (2016). Comparison of GIS-based interpolation methods for spatial distribution of soil organic carbon (SOC). Journal of the Saudi Society of Agricultural Sciences.

[32] Zekri, S. (2010). In: Comprehensive Master Plan for Al Batinah Coastal Area. Supreme Committee for Town Planning, Sultanate of Oman. 